\title{
Carry trades and commodity risk factors
}

\section{Citation for published version:}

Byrne, JP, Ibrahim, BM \& Sakemoto, R 2019, 'Carry trades and commodity risk factors', Journal of International Money and Finance, vol. 96, pp. 121-129. https://doi.org/10.1016/j.jimonfin.2019.04.004

\section{Digital Object Identifier (DOI): \\ 10.1016/j.jimonfin.2019.04.004}

\section{Link:}

Link to publication record in Heriot-Watt Research Portal

\section{Document Version:}

Peer reviewed version

\section{Published In:}

Journal of International Money and Finance

\section{Publisher Rights Statement:}

(C) 2019 Elsevier B.V.

\section{General rights}

Copyright for the publications made accessible via Heriot-Watt Research Portal is retained by the author(s) and / or other copyright owners and it is a condition of accessing these publications that users recognise and abide by the legal requirements associated with these rights.

\section{Take down policy}

Heriot-Watt University has made every reasonable effort to ensure that the content in Heriot-Watt Research Portal complies with UK legislation. If you believe that the public display of this file breaches copyright please contact open.access@hw.ac.uk providing details, and we will remove access to the work immediately and investigate your claim. 


\title{
Carry Trades and Commodity Risk Factors
}

\author{
Joseph P. Byrne ${ }^{1 *}$, Boulis Maher Ibrahim ${ }^{1}$ and Ryuta Sakemoto ${ }^{2}$
}

2nd March 2019

\begin{abstract}
This paper investigates the importance of commodity prices for the returns of currency carry trade portfolios. We adopt a recently developed empirical factor model to capture commodity commonalities and heterogeneity. Agricultural material and metal price risk factors are found to have explanatory power on the cross-section of currency returns, while commodity common and oil factors do not. Although stock market risk is strongly linked to currencies in developed countries, the agricultural material factor is more important for emerging currencies compared to the stock market factor. This suggests that emerging currencies are somewhat segmented from a common financial market shock.
\end{abstract}

Keywords: Currency Carry Trade, Commodity price, Factor Model, Hierarchical Model, Emerging Currencies

JEL codes: C58, F31, G12, G15

\footnotetext{
${ }^{1}$ Department of Accountancy, Economics and Finance, Heriot-Watt University.

* Corresponding author: Byrne, E-mail: j.p.byrne@hw.ac.uk.

${ }^{2}$ YJFX Inc and Keio Economic Observatory, Keio University, Tokyo, Japan.
} 


\section{Introduction}

The carry trade is an investment strategy that involves borrowing in a low interest rate currency and investing in a high interest rate currency. Many studies present evidence that the carry trade yields positive excess returns, and linear risk-based models may explain these returns. ${ }^{1}$ This rapidly expanding literature has identified several important factors in carry trade pricing. In this study, we extend this literature by building an empirical factor model in a data rich environment, with a particular focus upon the role of commodity prices.

Previous studies report that financial market or macro information, may be successful in modelling carry trade risk factors. In terms of financial market information, Menkhoff et al. (2012) find that global Foreign Exchange (FX) volatility innovations are negatively correlated with high interest rate currency portfolios. Other FX market information in the form of average U.S. dollar returns $(D O L)$ and the return difference between high and low currency portfolios $\left(H M L_{F X}\right)$ have also been found important, see Lustig et al. (2011). Further, Atanasov and Nitschka (2014), Dobrynskaya (2014), and Lettau et al. (2014) show that equity market downside risk can price carry returns better than the conventional capital asset pricing model (CAPM). ${ }^{2}$

Commodity prices however are a possible source of macro-finance information that may be useful for carry returns and, as yet, have not been formally considered in the cross-sectional carry trade literature. Chen and Rogoff (2003) and Chen et al. (2010) present time series evidence that the currencies of commodity producing countries, such as Australia and Canada, are linked to commodity prices over time. ${ }^{3}$ Also in a time series context, Bakshi and Panayotov (2013) show that the change in a commodity price index can predict excess returns of carry trades at quarterly frequency. Passari (2015) proposes the construction of currency portfolios based on currency returns as predicted by commodity prices. The high minus low commodity strategy factor in this context, however, does not price crosssectional portfolios. In a recent theoretical contribution, Ready et al. (2016) propose a model in which a

\footnotetext{
${ }^{1}$ Lustig and Verdelhan (2007) were the first to apply a risk-based model on the returns of currency carry trade portfolios. Other prominent papers in this field include Burnside (2011, 2012), Lustig and Verdelhan (2011), Lustig et al. (2011), Menkhoff et al. (2012), and Atanasov and Nitschka (2015).

${ }^{2}$ Macro fundamentals, such as consumption and production, may also be related to currency carry trades.

${ }^{3}$ Chen et al. (2010) show that exchange rates can predict a commodity price index at quarterly frequency.
} 
commodity importing country has more consumption risk compared to a commodity exporting country. They indicate that the interest rate in the commodity importing country is lower than that of the commodity exporting country due to precautionary savings.

The analysis in this paper contributes to the literature on carry trade returns on three fronts. First, we extend the work of Bakshi and Panayotov (2013), Passari (2015), and Ready et al. (2016) by utilising commodity prices as a risk factor for carry trade portfolios. We explore the cross-sectional relation between carry trade returns and commodity prices. In particular, this study investigates whether commodity common information can price cross-sectional currency portfolios. Given that the recent literature finds that commodity prices exhibit commonality (e.g., Byrne et al., 2013; Gospodinov and Ng, 2013; Alquist and Coibion, 2014; and West and Wang, 2014), this study focuses on a commodity common factor. However, different types of commodities may contain rather different information. ${ }^{4}$ Our approach examines common factors across commodity sectors and within particular commodity sectors.

This paper's second contribution is to exploit an empirical factor model to summarise a wide range of information, including the macro-finance data highlighted in the prior literature on carry trade returns. Ludvigson and $\operatorname{Ng}(2007,2009)$, Engel et al. (2015) and Filipou and Taylor (2015) use empirical factor models in time series forecast studies of stock markets, bond yields and exchange rates. When modelling a small number of cross-sectional portfolios, as with carry trades, the ability to effectively summarise a large array of risk factors becomes important. To this end, we employ the Dynamic Hierarchical Factor Model (DHFM) proposed by Moench et al. (2013). This model has a hierarchical structure that specifies common and block factors, which is useful in accounting for commodity heterogeneity. A further advantage is that empirical factors are more readily identifiable.

The paper's third contribution is that our approach to modelling commodities provides interpretation of the high minus low interest rate currency portfolio $\left(H M L_{F X}\right)$ in explaining carry returns. The $H M L_{F X}$ can capture the cross-sectional return differences of currency portfolios and is related to global market risk (see Lustig et al., 2011). Menkhoff et al. (2012) further report that $H M L_{F X}$ is also

\footnotetext{
${ }^{4}$ Yin and Han (2015) report that commodity price movements have heterogeneity across types of commodity. Chen et al. (2014) show that the combination of commodity prices has much more information than the aggregate commodity index.
} 
associated with FX market volatility. The exact content of $H M L_{F X}$, however, is still unclear, as pointed out by Burnside (2012), possibly because it is constructed from the carry portfolios themselves. Accordingly, we examine, in a time series context, whether our commodity prices factors have additional information that accounts for $H M L_{F X}$.

Our empirical results provide evidence that commodity price factors can price currency carry trades, and that there is heterogeneity across the types of commodity. We find that the agricultural material and metal factors are associated with the cross-section of currency excess returns. The agricultural material factor is especially linked to emerging currency portfolios, and the metal factor is related to developed currency portfolios. We also find the stock market risk is not linked to emerging currency portfolios. These findings are important, since the previous literature has not focused on the heterogeneity between developed and emerging currency portfolios. The related studies consider a world common factor, and developed and emerging currency portfolios have exposure to the same risk. Our finding suggests that there is risk that is somewhat segmented from financial markets but related to commodity prices. This commodity price risk is tied to emerging market currencies.

The remainder of this paper is organized as follows: Section 2 presents the method of constructing carry trade portfolios, Section 3 lays out the econometric framework and presents the empirical factor model, Section 4 discusses the empirical results, Section 5 presents further analysis, Section 6 adds the further discussion, and Section 7 concludes.

\section{Currency Portfolios}

We start by defining the currency excess return and describing the construction of carry trade portfolios. Let $s_{t}$ be the log of the spot exchange rate at time $t$ in foreign currency per unit of domestic currency, and $f_{t}$ be the log of the forward exchange rate at time $t$ to be delivered at time $t+1$. A rise in $s_{t}$ is a domestic currency appreciation, and the domestic currency is assumed to be the U.S. dollar (USD). 
Following Lustig et al. (2011), the currency carry return is computed as: ${ }^{5}$

$$
r_{t+1}=f_{t}-s_{t+1}
$$

This strategy is implemented by selling the dollar forward, $f_{t}$, in the current period and buying the dollar spot, $s_{t+1}$, in the next period. We sort currencies into six portfolios, P1 to P6, based on their forward discounts, $f_{t}-s_{t}$. P1 contains the lowest interest rate currencies and P6 contains the highest interest rate currencies. These are rebalanced at the end of each month. The log excess return of a portfolio is calculated as the equally-weighted average of the log excess returns of the currencies in that portfolio. Following Lustig et al. (2011), we account for trading costs using bid-ask spreads.

\section{Econometric Framework}

\subsection{Risk Premium Estimation}

This section describes Fama and MacBeth's (1973) two-pass estimation procedure to test risk premia, which we adopt in this paper. This procedure is used to estimate risk premia, $\lambda$, and factor beta $\beta_{i}$ for portfolio $i$. The expected excess return for portfolio $i$ is:

$$
E\left[r_{i}\right]=\lambda^{\prime} \beta_{i}
$$

The risk premia, $\lambda$, have the same values across portfolios, and $\beta_{i}$ is the portfolio $i$ 's exposure to risk, which differs across portfolios. The factor betas are estimated by time series regressions, where each portfolio's excess return is regressed on the risk factor $h_{t}$ :

$$
r_{i, t}=\alpha_{i}+h_{t}^{\prime} \beta_{i}+\epsilon_{i, t}
$$

where $\epsilon_{i, t}$ is an error term. Burnside (2011) highlights the importance of checking whether betas are statistically and economically significant. The risk premia are then obtained by a cross-sectional regression where the portfolios' time series average excess returns are regressed on the estimated betas $\hat{\beta}_{i}$ :

$$
E\left[r_{i}\right]=\lambda^{\prime} \hat{\beta}_{i}+\eta_{i}
$$

\footnotetext{
${ }^{5}$ This return is related to violation of the Uncovered Interest rate Parity (UIP). See Appendix A in the online supplement.
} 
where $\eta_{i}$ is an error term. Since these betas are estimated variables, estimation uncertainty should be taken into account for statistical inference. Accordingly, we follow Burnside (2011) and use the Shanken (1992) standard errors to account for estimation uncertainty. ${ }^{6}$

\subsection{Empirical Factor Model}

Our empirical strategy in examining the importance of commodity prices and other factors is to adopt a data reduction method. This subsection describes our approach to estimate the empirical factors in the data rich environment. We estimate three types of common factors: across our entire macro-finance dataset, across all commodity prices, and within a particular group of commodity prices. To this end, we use the Dynamic Hierarchical Factor Model (DHFM) proposed by Moench et al. (2013). Conventional empirical factor models that extract factors using principal components have limited flexibility and present a difficulty in interpreting the factors. Instead, if we have some prior knowledge of the data structure, the DHFM can help with the identification of the empirical factor model. A block factor is decomposed into a common factor and block specific shocks, and a subblock factor is decomposed into a block factor and subblock specific shocks by the DHFM. ${ }^{7}$

We start building the DHFM by arranging the data into three blocks: commodity price (COM), finance $(F I N)$ and real economy $(E C O)$. The commodity price block has the following four subblocks: food prices $(F O O)$, agricultural material prices $(A G R)$, metals $(M E T)$, and oil $(O I L)$. The finance block has the following three subblocks: stock market $(S T O)$, interest rate $(I N T)$, and money $(M O N)$. The real economy block has the following five subblocks: income and consumption $(I N C)$, production $(P R O)$, employment $(E M P)$, house $(H O U)$, and price $(P R I)$. We partition the real economy and finance blocks as in Stock and Watson (2005).

\footnotetext{
${ }^{6}$ Jagannathan and Wang (1998) point out that the Shanken (1992) standard errors are inappropriate if heteroscedasticity is present. In Appendix B we also report the estimation results by the Generalized Method of Moments (GMM) as in Cochrane (2005).

${ }^{7}$ Our estimation model is described in Appendix $\mathrm{C}$ in the online appendix.
} 


\section{Empirical Results}

\subsection{Data}

To calculate currency excess returns, daily spot and one-month forward exchange rates against the USD are obtained from Datastream. This data contains bid and ask quotes and end of month values extracted from the daily data series considered by Lustig et al. (2011). The dataset covers the same 37 countries in Lustig et al. (2011), and we also construct separate developed country portfolios from emerging country portfolios.

The monthly dataset extends from February 1983 to December 2013. Since not all series start from February 1983, the total number of exchange rates varies during this period. As data on most of the emerging market exchange rates is available from January 1997, the emerging country portfolios start from January 1997. Following Lustig et al. (2011) and Menkhoff et al. (2012), the older currencies of the Euro member countries are replaced by the Euro after January 1999, and outliers pointed out in Lustig et al. (2011) are deleted. ${ }^{8}$

Next, we describe the dataset used to estimate the risk factors by the empirical factor model. We include the log of real commodity prices, and use 23 non-fuel commodity prices, and three oil prices. We select 23 non-fuel commodities based upon the widely used Commodity Price Index of Grilli and Yang (1988). This data is from the IMF and the World Bank, and real commodity prices are computed using the U.S. Consumer Price Index (CPI).

We also employ a balanced panel of 102 monthly series to test a wide range of information as in Stock and Watson (2005). We test whether a common factor across commodity prices and the other macroeconomic data contains useful information in pricing currency carry trades. The motivation is that these estimated factors may capture a wide range of alternative macro and financial factors associated with currency excess returns, as pointed out by Ludvigson and $\mathrm{Ng}(2007,2009)$. In general, this dataset contains the following U.S. macroeconomic series.

\footnotetext{
${ }^{8}$ We also pre-treat the dataset using the approach of Darvas (2009) and Cenedese et al. (2014).
} 


\subsection{Cross-sectional Results}

We now turn to our core estimation results of the currency excess returns commodity linear factor model in Equation (4). ${ }^{9}$ Table 1 presents our first set of cross-sectional asset pricing test results using the commodity price factors. The estimated risk premia $(\lambda)$, root mean-squared error (RMSE), pricing error tests ( $\chi^{2}$ and $p$-value), and $R^{2}$ are reported. We estimate the cross-sectional model without a constant term. Burnside (2011) highlights that if the constant term is included, it can account for a large part of the variation in the data, inflating $R^{2}$.

We begin with the commodity price factors, which represent the main focus of this study. This estimation examines whether commodity group information is useful in pricing currency carry trades, and considers four commodity factors: food, agricultural material, metal, and oil, are compared. In addition, the average U.S. dollar factor, DOL, is included as in Lustig et al. (2011) and Menkhoff et al. (2012). DOL loads onto all portfolios equally reflecting the fact that it represents the average currency excess return for a U.S. investor who invests in foreign currencies.

The results in Table 1 Panel A present evidence that the agricultural material $(S B-A G R)$ and metal $(S B-M E T)$ factors can price currency portfolios. Column (1) reports the risk premium of the agricultural material factor to be statistically significant at the $1 \%$ level and its impact is $3.4 \%(=0.30$ $\times 12$ ) per annum. The high $R^{2}$ and the lower RMSE indicate a good model performance. Column (2) indicates that the metal factor has a statistically significant risk premium and its impact is similar to that of the agricultural material factor. ${ }^{10}$ To study the agricultural and metal factors further, we investigate factor exposure of commodity importing and exporting countries. Ready et al. (2016) report that commodity importing and exporting countries have heterogeneous exposure to global productivity shocks. We replicate the Ready et al. (2016) results in Figure A-2, and they indicate that our commodity factors are linked to global production shocks, since commodity importing and exporting countries have opposite exposure to these commodity factors.

The results for the food and oil factors are presented in columns (3) and (4) in Table 1. Although

\footnotetext{
${ }^{9}$ We report time series results in Table A-4.

${ }^{10}$ For robustness, the CRB Raw industrial material subindex return, which is used in Bakshi and Panayotov (2013) and IMF agricultural material and metal index returns are also adopted.
} 
the food factor model has a high $R^{2}$ and a small RMSE, we interpret these results cautiously because the estimated betas are not statistically significant as reported in Table A-4 in the appendix. The oil factor is not associated with the cross-section of currency excess returns. This finding is intuitive, since oil exporting countries, such as Saudi Arabia and Kuwait, are not high interest rate countries.

[Table 1 about here]

The results of the finance block factors are presented in Panel B of Table 1. As Lettau et al. (2014) and Dobrynskaya (2014) provide evidence that financial market information is linked to currency carry trades, we test whether financial factors extracted by the DHFM can price the cross-section of currency portfolios. Column (5) provides the result of the stock market factor $(S B-S T O)$, which confirms that this factor is related to cross-sectional currency excess returns. The risk premium is statistically significant at the the $1 \%$ level and is $3.8 \%$ per annum. Dobrynskaya (2014) reports that the CAPM cannot account for currency excess returns, but downside stock market risk is crucial. Since our stock market factor is negatively correlated with stock market volatility innovations, it could be related to downside market risk. Our stock market factor, however, is not a simple downside risk factor, because it includes the size, value, and momentum factors of Fama and French (1993) and Carhart (1997). The remaining columns in Panel B report that the other finance subblock factors are less promising than the stock market factor.

\section{3. $H M L_{F X}$ and Commodity Factors}

Given the commodity factors are related to the cross-sectional currency portfolios, we focus on $H M L_{F X}$ which has been used in the cross-sectional literature to identify carry returns. This factor is computed as the return spread between high and low currency portfolios, and Lustig et al. (2011) links this popular factor to global stock market risk. The relationship with commodity prices, however, has not been investigated in the literature. We regress $H M L_{F X}$ on the agricultural material and metal factors. Rows (1) and (2) in Table 2 are our base results, and: both agricultural material and metal factors are significant at the $1 \%$ level with a large economic impact. For instance, this economic impact is 
illustrated by a one standard deviation change in the agricultural material leading to a $6.6 \%$ change in $H M L_{F X}$. We also control for the effect of the global FX volatility innovations $\left(\triangle V O L_{F X}\right)$ of Menkhoff et al. (2012) in rows (3) and (4) in Table 2. The magnitude reduces slightly, but both coefficients remain statistically significant at the $1 \%$ level.

Next, we test which of the two factors is more important for $H M L_{F X}$ in Table 2 rows (5) and (6). As the agricultural material and metal factors are correlated, the metal factor is orthogonalized to the agricultural material factor in row (5), which is the same approach of Menkhoff et al. (2012). Now, the orthogonalized metal factor, $M E T^{o r t h}$, becomes insignificant. In contrast, the orthogonalized agricultural material factor, $A G R^{\text {orth }}$, remains significant at the $1 \%$ level in row (6). These results imply that the agricultural material factor drives out the metal factor. We also compare our factors and the IMF index in the Online Appendix and the results confirm that our factors have a dominant effect.

Finally, we examine whether the commodity factors remain significant with our stock market factor. The stock market factor is orthogonalized to the agricultural material and metal factors in rows (7) and (8) of Table 2. We repeat the opposite operations in rows (9) and (10). ${ }^{11}$ These results show that the commodity and stock market factors have different information, and both are highly associated with $H M L_{F X}$. Hence our approach in this paper is useful in explaining the time series movement in the widely cited $H M L_{F X}$ for carry returns.

A possible explanation for the difference between commodity and stock market information is that the former is mainly related to emerging currencies and the latter is tied to currencies in advanced economies. The previous literature does not point out this difference and focuses on the common risk. For instance, Lustig et al. (2011) propose a theoretical model based upon a no-arbitrage model, and the key assumption is that each currency has a different exposure to a common shock. They use stock market volatility as a proxy for the common shock. Subsequent empirical studies support this assumption and demonstrate that downside stock market is an important risk factor for carry trades (e.g., Atanasov and Nitschka, 2014; Dobrynskaya, 2014 and Lettau et al. 2014). However, some emerging countries' currencies may not be tied to world financial market risk, perhaps because they do not have developed

\footnotetext{
${ }^{11}$ For further robustness, the world stock market volatility innovations are used in Table A-5 in the appendix.
} 
financial markets. In fact, Habib and Stracca (2012) show that a reversal of carry trades during the financial crisis has a clear pattern only in liquid currencies. For the less liquid currencies of emerging countries, commodity prices instead are more important determinants of exchange rates. Bodart et al. (2012) focus on emerging countries that are dependent upon the export of a single commodity good and find that when commodity prices increase, the currencies appreciate. Hence, commodity price information is strongly linked to emerging currencies, while these currencies' link to stock market information is rather weak. In the next section we investigate this further and test whether the stock market and commodity factors price both developed and emerging currencies' portfolios.

[Table 2 about here]

\section{Developed Countries and Emerging Market Carry Portfo- lios}

Given the evidence of the heterogeneous information contents of the commodity and stock market factors presented in Table 3, we explore whether they are linked to financial market development. To this end, we split the currency dataset into developed country currencies and emerging country currencies. Lustig et al. (2011) use the same developed country dataset as a robustness check. We also consider an emerging country category, since some emerging countries are commodity exporters and commodity prices may have a particular effect on their interest rates and exchange rates.

Panel A in Table 3 reports estimates of risk premia on carry returns of currencies that belong to developed countries. The results in column (1) show that the agricultural material factor cannot price developed country portfolios, but columns (2) and (3) show that the metal and stock market factors account for these portfolios. This suggests that metal prices are related to the U.S. stock market, as pointed out by Fama and French (1988). This result does not mean that both factors contain the same information, because the previous section provides evidence that the metal factor remains significant even when the stock market factor is controlled for.

We turn to the emerging country results in Panel B of Table 3. The results in column (4) show 
that agricultural material can price the emerging currency portfolios. Surprisingly, the risk premia on the stock market and the metal factors vanish in columns (5) and (6). This implies that a risk factor for developed country currencies differs from that for emerging currencies, and that developed countries are connected to stock market risk. This link is intuitive, since developed country currencies are more liquid, and investors usually implement carry trades using mainly developed country currencies. Jylhä and Suminen (2011) find money flows to hedge funds are related to carry trade returns in developed countries. Our result also implies that stock and commodity markets risks may be somewhat segmented. This conclusion is consistent with Gorton and Rouwenhorst (2006), who find a low correlation between equity and commodity market returns.

In summary, we find the agricultural material factor strongly related to emerging countries, and the stock market and metal factors are mainly affected by advanced economies. This heterogeneity comes from developed country currencies, which are more liquid and regarded as an investable asset class.

[Table 3 about here]

\section{Further Discussion}

Having found that the commodity price commonalities and heterogeneities are important in accounting for cross-sectional currency portfolio returns, this section discusses how our findings are related to the literature. The important innovation in this study is the simultaneous consideration of commodity price commonalities and heterogeneities. Bakshi and Panayotov (2013), and Passari (2015) investigate relationships between commodity prices and future currency returns. They do not examine whether commodity prices explain cross-sectional currency portfolios, which is investigated in this study. A more important difference is that these studies employ a single index, or one commodity price, and hence this might miss important information that could be extracted from commodity prices. Recent studies report that overlapping information across commodity prices predicts macroeconomic variables (e.g. Gospodinov and Ng, 2013).

We find that different commodity groups are related to different carry trade portfolios. This is the 
important extension to Ready et al. (2016) who propose a commodity factor based upon heterogeneity between commodity importing and exporting countries. They investigate only developed countries which have the detailed trade data that is required to construct their factor. We consider another type of carry heterogeneity, that is the difference between developed and emerging country currencies. These two groups differ significantly in terms of trading volume, liquidity, and financial regulation. Furthermore, business cycles of these two groups are not completely converged (Kose et al, 2012).

Our results indicate that important, yet different carry information is provided by metal and agricultural material prices. The former is associated with developed country currencies and global financial markets, while the latter is linked to emerging country currencies. Verdelhan (2018) highlights that two different kind of risk factors are required in generating UIP deviations. He proposes a log normal stochastic discount factor $\left(\mathrm{SDF}, m_{i, t+1}\right)$ process that has two global shocks, $u_{w, t+1}$ and $u_{g, t+1}$ (e.g. Cox et al. 1985):

$$
-m_{i, t+1}=a_{i}+\chi_{i} \sigma_{i, t}^{2}+\tau_{i} \sigma_{w, t}^{2}+\gamma_{i} \sigma_{i, t} u_{i, t+1}+\delta_{i} \sigma_{w, t} u_{w, t+1}+\kappa_{i} \sigma_{i, t} u_{g, t+1}
$$

where $\sigma_{i, t}^{2}$ is country specific volatility and $\sigma_{w, t}^{2}$ is global volatility, and $u_{i, t+1}$ is a country specific shock,

while $a_{i}, \chi_{i}, \tau_{i}, \gamma_{i}, \delta_{i}$, and $\kappa_{i}$ are parameters. Our results suggest that one global shock could be metal prices that is a driving force for changes in developed country currencies The other is the agricultural material shock that is connected to emerging country currencies.

\section{Conclusion}

This paper investigates a range of commodity price risk factors for portfolios of currency carry trades. Commodity exporting and importing countries are related to interest rates, as shown by Ready et al. (2016) in advanced economies. Moreover, several high interest rate emerging countries are commodity exporters, thus, commodity prices may affect currency carry trade returns. This study focuses on common information across commodity prices and within certain groups of commodities. Since the importance of commodity common information have been investigated recently (e.g., Byrne et al., 2013; Gospodinov and Ng, 2013; Alquist and Coibion, 2014 and West and Wang, 2014), we extract common 
factors from overall commodity prices, and from specific commodity groups.

We find commodity prices are important risk factors for the returns of currency carry trades. Although Bakshi and Panayotov (2013) link a commodity price index with future currency excess returns, we focus on the cross-sectional relation between currency excess returns and commodity risk factors. We find the agricultural and metal factors are related to currency trade risk, but broad commodity and oil price factors fail to explain currency excess returns. These heterogeneous results support the use of the dynamic hierarchical factor model.

We present evidence that the agricultural material factor is linked to currencies of emerging countries and the metal factor is related to currencies of developed countries. Although stock market information is important in pricing currency carry trades, as shown by Dobrynskaya (2014) and Lettau et al. (2014), this study reveals that this information is weakly associated with emerging currencies. We find that commodity information is a more dominant factor for emerging currencies, since emerging countries do not have liquid financial markets, and hence are somewhat segmented from world financial market risk. This result is supported by the finding of Habib and Stracca (2012) who present a significant reversal of carry trades during the financial crisis only in developed markets when stock markets crashed. Our findings are important, since the previous literature focuses on the common risk among developed and emerging markets while we focus on heterogeneity between these markets. Our results call for further research into theoretical models that link commodity price risk to financial market risk. 
Table 1 Cross-sectional Asset Pricing: Commodity and Finance Subblocks

\begin{tabular}{|c|c|c|c|c|}
\hline \multicolumn{5}{|c|}{ Panel A: Commodity Block } \\
\hline & (1) & $(2)$ & $(3)$ & $(4)$ \\
\hline & $\lambda$ & $\lambda$ & $\lambda$ & $\lambda$ \\
\hline$D O L$ & 0.15 & 0.15 & 0.15 & 0.16 \\
\hline & $(0.12)$ & $(0.12)$ & $(0.12)$ & $(0.12)$ \\
\hline$S B-A G R$ & $\begin{array}{l}0.30^{* * * *} \\
(0.12)\end{array}$ & & & \\
\hline$S B-M E T$ & & $\begin{array}{c}0.31^{* *} \\
(0.12)\end{array}$ & & \\
\hline$S B-F O O$ & & & $\begin{array}{c}0.87^{*} \\
(0.48)\end{array}$ & \\
\hline$S B-O I L$ & & & & $\begin{array}{r}1.73 \\
(1.58)\end{array}$ \\
\hline$R^{2}$ & 0.57 & 0.53 & 0.81 & 0.20 \\
\hline RMSE & 0.10 & 0.11 & 0.07 & 0.14 \\
\hline$\chi^{2}$ & $11.97^{* *}$ & $12.30^{* *}$ & 1.69 & 5.35 \\
\hline$[p$-value $]$ & {$[0.02]$} & {$[0.02]$} & {$[0.79]$} & {$[0.25]$} \\
\hline
\end{tabular}

Panel B: Finance Block

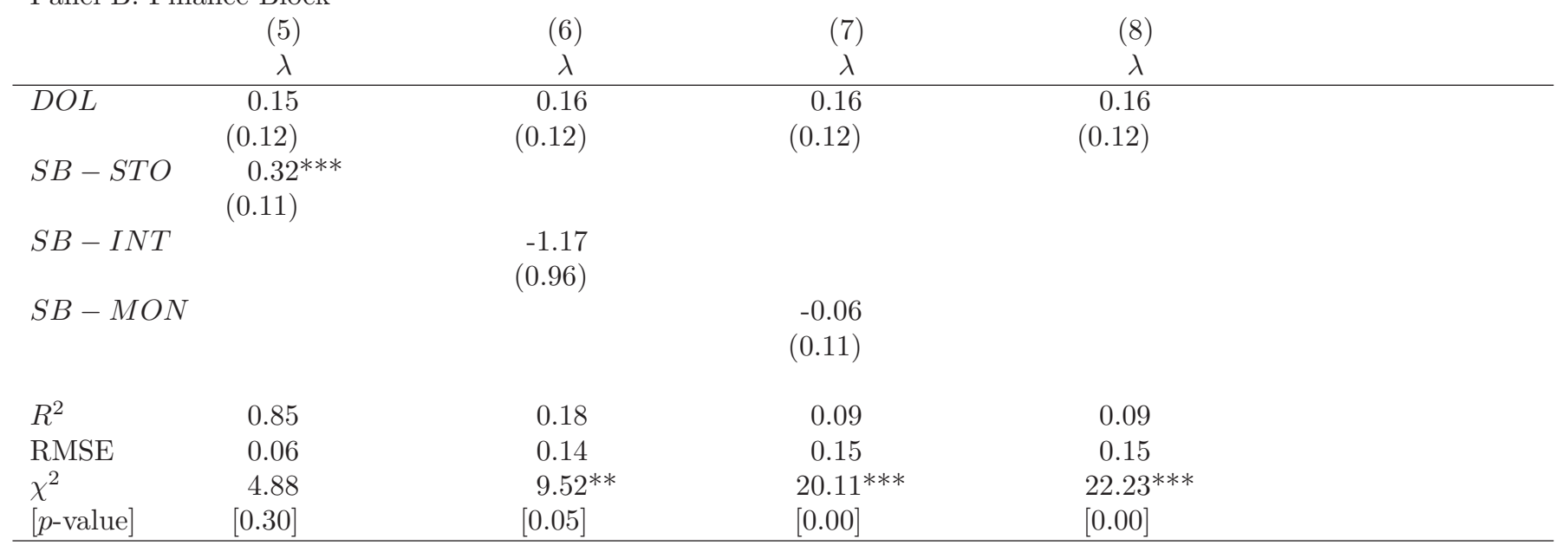

Notes: This table reports cross-sectional pricing results of the linear factor model based on the commodity prices or financial risk factors. The test assets are excess returns of six carry trade portfolios. The coefficient of factor risk premium $\lambda$ in Equation (4) is estimated by the procedure of Fama and MacBeth (1973). Abbreviations of the factor variables are reported in the first column. $D O L$ is the average dollar risk factor. $S B-A G R$ is the agricultural material prices, $S B-M E T$ is the metal, $S B-F O O$ is the food prices, $S B-O I L$ is the oil, $S B-S T O$ is the stock market, $S B-I N T$ is the interest rate, and $S B-M O N$ is the money factors estimated by the Dynamic Hierarchical Factor Model. Shanken (1992) standard errors are reported in parentheses. The $R^{2}$ is a measure of fit between the sample mean and the predicted mean returns. The RMSE is the root of mean-squared error and is reported in percentage points. The $\chi^{2}$ test statistics of pricing errors are reported and the null hypothesis is that there is no pricing error. $p$-values are reported in square brackets. ***, and $* * *$ indicate significance at the $10 \%, 5 \%$ and $1 \%$ levels, respectively. The sample period is from February 1983 to December 2013. 
Table 2 Time Series Regression with $H M L_{F X}$

\begin{tabular}{|c|c|c|c|c|c|c|c|c|}
\hline & $A G R$ & $M E T$ & $A G R^{\text {orth }}$ & $M E T^{o r t h}$ & STO & STO ${ }^{\text {orth }}$ & $\Delta V O L_{F X}$ & $\operatorname{adj} R^{2}$ \\
\hline (1) & $\begin{array}{l}1.40^{\text {*** }} \\
(0.42)\end{array}$ & & & & & & & 0.05 \\
\hline$(2)$ & & $\begin{array}{l}1.28^{* * *} \\
(0.43)\end{array}$ & & & & & & 0.04 \\
\hline (3) & $\begin{array}{l}1.18^{\text {**** }} \\
(0.32)\end{array}$ & & & & & & $\begin{array}{l}-7.23^{* * *} \\
(1.29)\end{array}$ & 0.15 \\
\hline$(4)$ & & $\begin{array}{l}0.87^{* * *} \\
(0.31)\end{array}$ & & & & & $\begin{array}{l}7.02^{* * *} \\
(1.32)\end{array}$ & 0.13 \\
\hline$(5)$ & $\begin{array}{l}1.19^{* * * *} \\
(0.31)\end{array}$ & & & $\begin{array}{r}0.49 \\
(0.31)\end{array}$ & & & $\begin{array}{l}-6.90^{* * *} \\
(1.24)\end{array}$ & 0.15 \\
\hline (6) & & $\begin{array}{l}0.87^{* * *} \\
(0.28)\end{array}$ & $\begin{array}{l}1.00^{* * *} \\
(0.34)\end{array}$ & & & & $\begin{array}{l}-6.90^{* * *} \\
(1.21)\end{array}$ & 0.15 \\
\hline$(7)$ & $\begin{array}{l}1.20^{\text {**** }} \\
(0.31)\end{array}$ & & & & & $\begin{array}{l}0.87^{* * *} \\
(0.32)\end{array}$ & $\begin{array}{l}-6.69^{* * *} \\
(1.24)\end{array}$ & 0.17 \\
\hline$(8)$ & & $\begin{array}{l}0.89^{* * *} \\
(0.30)\end{array}$ & & & & $\begin{array}{c}0.78^{* *} \\
(0.33)\end{array}$ & $\begin{array}{l}-6.60^{* * *} \\
(1.26)\end{array}$ & 0.14 \\
\hline$(9)$ & & & $\begin{array}{l}1.17^{* * *} \\
(0.31)\end{array}$ & & $\begin{array}{l}0.92^{* * *} \\
(0.32)\end{array}$ & & $\begin{array}{l}-6.70^{* * *} \\
(1.24)\end{array}$ & 0.17 \\
\hline (10) & & & & $\begin{array}{l}0.78^{* * *} \\
(0.33)\end{array}$ & $\begin{array}{l}0.93^{* * *} \\
(0.30)\end{array}$ & & $\begin{array}{l}-6.60^{* * *} \\
(1.25)\end{array}$ & 0.14 \\
\hline
\end{tabular}

Notes: This table shows results for time series regressions of $H M L_{F X}$ on a constant and factors. $H M L_{F X}$ is the high minus low currency portfolios as in Lustig et al. (2011). AGR is the agricultural material prices, MET is the metal, and $S T O$ is the stock market factors estimated by the Dynamic Hierarchical Factor Model. This table also investigates the orthogonal factors, based upon Menkhoff et al. (2012). AGR orth is the orthgonalized agricultural material prices, $M E T^{\text {orth }}$ is the orthgonalized metal, and $S T O^{\text {orth }}$ is the orthgonalized stock market factors. $\triangle V O L_{F X}$ is the global FX volatility innovations as in Menkhoff et al. (2012). The estimated coefficient for the constant term are not reported. The standard errors are reported in parentheses and obtained by the Newey and West (1987) procedure with optimal lag selection according to Andrews (1991). The adjusted $R^{2}$ are also reported. ***, and *** indicate significance at the $10 \%$, $5 \%$ and 1\% levels, respectively. The sample period is from February 1983 and December 2013. 
Table 3 Cross-sectional Asset Pricing: Developed and Emerging Currencies

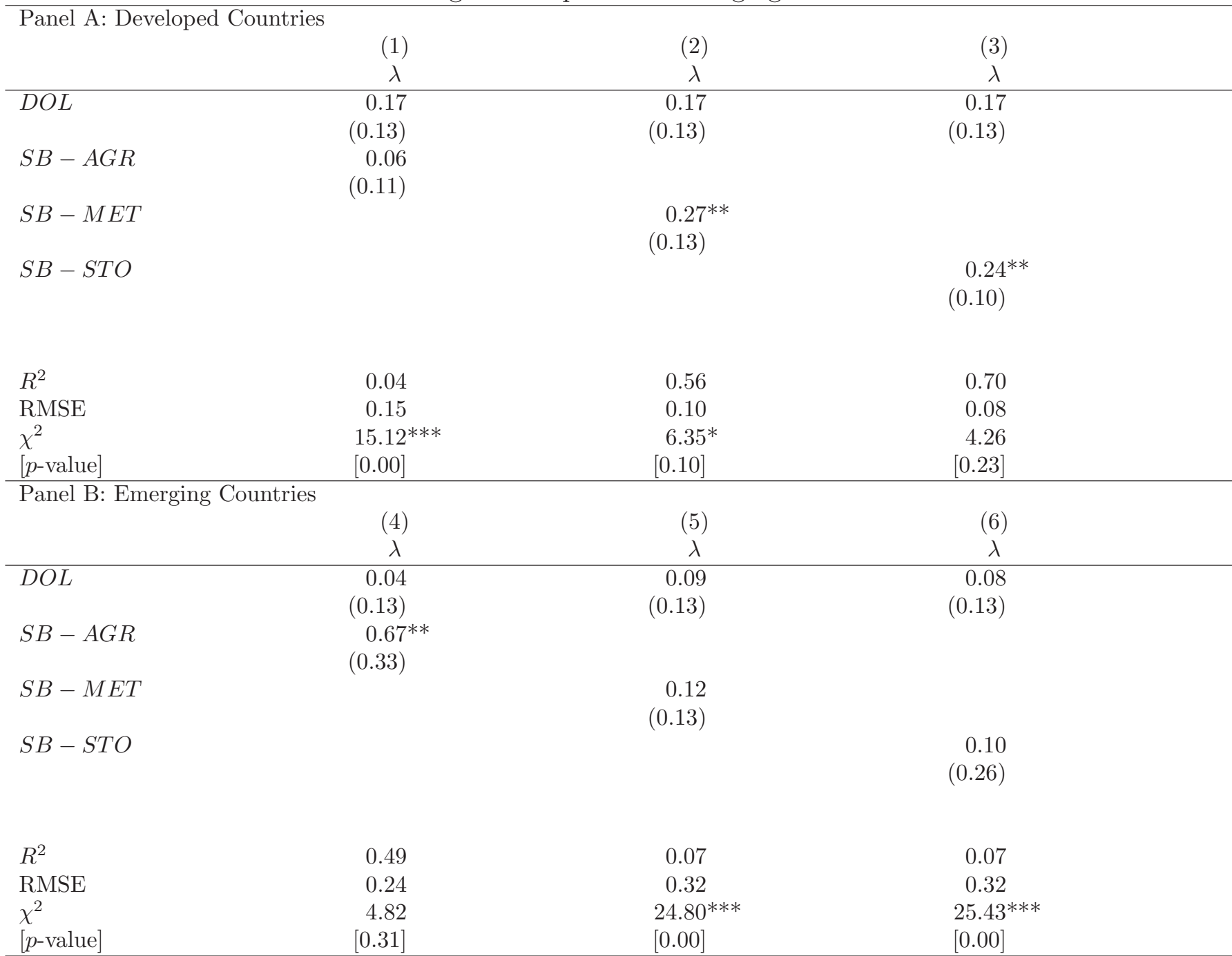

Notes: This table reports cross-sectional pricing results of the linear factor model based on the commodity prices or financial risk factors. The test assets are excess returns of five developed country carry trade portfolios or six emerging country carry trade portfolios. The coefficient of factor risk premium $\lambda$ in Equation (6) is estimated by the procedure of Fama and MacBeth (1973). Abbreviations of the factor variables are reported in the first column. $D O L$ is the average dollar risk factor. $S B-A G R$ is the agricultural material prices, $S B-M E T$ is the metal, and $S B-S T O$ is the stock market factors estimated by the Dynamic Hierarchical Factor Model. Shanken (1992) standard errors are reported in parentheses. The $R^{2}$ is a measure of fit between the sample mean and the predicted mean returns. RMSE is the root of mean-squared error and is reported in percentage points. The $\chi^{2}$ test statistics of pricing errors are reported and the null hypothesis is that there is no pricing error. $p$-values are reported in square brackets. $* * *$, and *** indicate significance at the $10 \%, 5 \%$ and $1 \%$ levels, respectively. The sample period in developed countries is from February 1983 to December 2013 and that in emerging countries is from January 1997 to December 2013. 


\section{References}

Alquist, R. and Coibion, O. (2014) Commodity-price comovement and global economic activity, unpublished working paper 20003, National Bureau of Economic Research.

Andrews, D. (1991) Heteroskedasticity and autocorrelation consistent covariance matrix estimation, Econometrica, 59, 817-858.

Ang, A. and Chen, J. (2010), Yield curve predictors of foreign exchange returns, unpublished working paper, AFA 2011.

Atanasov, V. and Nitschka, T. (2014) Currency excess returns and global downside market risk, Journal of International Money and Finance, 47, 268-285.

Atanasov, V. and Nitschka, T. (2015) Foreign currency returns and systematic risks, Journal of Financial and Quantitative Analysis, 50, 231-250.

Bakshi, G. and Panayotov, G. (2013) Predictability of currency carry trades and asset pricing implications, Journal of Financial Economics, 110, 139-163.

Bodart, V., Candelon, B., and Carpantier (2012) Real exchange rates in commodity producing countries: a reappraisal, Journal of International Money and Finance, 31, 1482-1502.

Burnside, C. (2011) The cross section of foreign currency risk premia and consumption growth risk: comment, American Economic Review, 101, 3456-3476.

Burnside, C. (2012). Carry trades and risk, in: J. James, I. Marsh, and L. Sarno (eds.), Handbook of Exchange Rates, Hoboken, NJ: John Wiley \& Sons, pp. 283-312.

Byrne, J., Fazio, G., and Fiess, N. (2013) Primary commodity prices: co-movements common factors and fundamentals, Journal of Development Economics, 101, 16-26.

Carhart, M. (1997) On persistence in mutual fund performance, Journal of Finance, 52, 57-82.

Cenedese, G., Sarno, L., and Tsiakas, I. (2014) Foreign exchange risk and the predictability of carry trade returns, Journal of Banking and Finance, 42, 302-313.

Chen, Y-c. and Rogoff, K. (2003) Commodity currencies, Journal of International Economics, 60, 133-160.

Chen, Y-c., Rogoff, K., and Rossi, B. (2010) Can exchange rates forecast commodity prices?, Quarterly Journal of Economics, 125, 1145-1194.

Chen, Y-c., Turnovsky, S., and Zivot, E. (2014) Forecasting inflation using commodity price aggregation. Journal of Econometrics, 183, 117-134.

Cochrane, J. (2005), Asset Pricing. Revised edition, Princeton: Princeton University Press. 
Cox, J., Ingersoll, J., and Ross, S. (1985) A theory of the term structure of interest rates. Econometrica, 53, 385408 .

Darvas, Z. (2009) Leveraged carry trade portfolios, Journal of Banking and Finance, 33, 944-957.

Dobrynskaya, V. (2014) Downside market risk of carry trades, Review of Finance, 18, 1885-1913.

Engel, C., Mark, N., and West, K (2015) Factor model forecasts of exchange rates, Econometrics Review, 34, 32-55.

Fama F, and French, K. (1988) Business cycles and the behavior of metals prices, Journal of Finance, 43, 1075-1093.

Fama, F. and French, K. (1993) Common risk factors in the returns on stocks and bonds, Journal of Financial Economics, 33, 3-56.

Fama, F. and MacBeth, J. (1973) Risk, return, and equilibrium: empirical tests, Journal of Political Economy, 81, 607-636.

Filippou I. and Taylor, M. (2015) The common macro factors and currency premia, Journal of Financial and Quantitative Analysis, in press.

Gorton, G. and Rouwenhorst, G. (2006) Facts and fantasies about commodity futures, Financial Analysts Journal, 62, 47-68.

Grilli, E. and Yang, M. (1988) Primary commodity prices, manufactured goods prices, and the terms of trade of developing countries: what the long run shows, World Bank Economic Review, 2, 1-47.

Gospodinov, N. and Ng, S. (2013) Commodity prices, convenience yields and inflation, Review of Economics and Statistics, 95, 206-219.

Habib, M. and Stracca, L. (2012) Getting beyond carry trade: what makes a safe haven currency, Journal of International Economics, 87, 50-64.

Jagannathan, R., and Wang, Z. (1998) An asymptotic theory for estimating beta-pricing models using cross-sectional regression, Journal of Finance, 53, 1285-1309.

Jylhä, P. and Suominen, M. (2011) Speculative capital and currency carry trades, Journal of Financial Economics, 99, 66-75.

Kose, A.,, Otrok, C., and Prasad, E. (2012) Global business cycles: convergence or decoupling? International Economic Review, 53, 511-538.

Lettau, M. Maggiori, M., and Weber, M. (2014) Conditional risk premia in currency markets and other asset classes, Journal of Financial Economics, 114, 197-225.

Ludvigson, C. and Ng, S. (2007) The empirical risk-return relation: a factor analysis approach, Journal of Financial Economics, 83, 171-222. 
Ludvigson, C. and Ng, S. (2009) Macro factors in bond risk premia, Review of Financial Studies, 22, 5027-5067.

Lustig, H., Roussanov N., and Verdelhan, A. (2011) Common risk factors in currency markets, Review of Financial Studies. 24, 3731-3777.

Lustig, H. and Verdelhan, A. (2007) The cross section of foreign currency risk premia and consumption growth risk, American Economic Review,97, 89-117.

Lustig, H. and Verdelhan, A. (2011) The cross section of foreign currency risk premia and consumption growth risk: reply, American Economic Review, 101, 3477-3500.

Menkhoff, L., Sarno, L., Schmeling, M., and Schrimpf, A. (2012) Carry trades and global foreign exchange volatility, Journal of Finance, 67, 681-718.

Moench, E., Ng, S., and Potter, S. (2013) Dynamic hierarchical factor models, Review of Economics and Statistics, 95, 1811-1817.

Newey, W. and West, K. (1987) A simple, positive semi-definite, heteroskedasticity and autocorrelation consistent covariance matrix, Econometrica, 55, 703-708.

Passari, E. (2015) Commodity currencies revisited, unpublished working paper.

Ready, R., Roussanov, N., and Ward, C. (2016) Commodity trade and the carry trade: a tale of two countries, Journal of Finance, in press.

Shanken, J. (1992) On the estimation of beta-pricing models, Review of Financial Studies, 5, 1-33.

Stock, J. and Watson, M. (2005) Implications of dynamic factor models for VAR analysis, unpublished working paper 11467, National Bureau of Economic Research.

Verdelhan, A. (2018). "The share of systematic variation in bilateral exchange rates." Journal of Finance, 73, 375-418.

West, K., and Wong, K. (2014) A factor model for co-movements of commodity prices, Journal of International Money and Finance, 42, 289-309.

Yin, L. and Han, L. (2015) Co-movement in commodity prices: global, sectoral and commodity-specific factors, Economic Letters, 126, 96-100. 


\title{
Carry Trades and Commodity Risk Factors
}

\author{
2nd March 2019
}

\section{Online Supplement, Not for Publication}

This Online supplement provides further information and several robustness checks. Section A sets out the relationship to Uncoverd Interest rate Parity; Section B provides the detail on the Generalized Method of Moments estimation method; Section C shows the list of countries this study analyses; Section D describes the data treatment; Section E presents the relationship between our empirical results and commodity exporting/importing countries; Section F provides further robustness tests using individual currencies.

\section{A. Uncovered Interest Parity}

A carry trade is an investment strategy exploiting the empirical failure of Uncoverd Interest rate Parity (UIP). The failure of UIP is often observed in many currencies and is known as the forward premium puzzle. Lewis (1995) and Engel (1996) provide reviews of this puzzle. The currency excess return is written as:

$$
r_{t+1} \approx i_{t}^{*}-i_{t}-\left(E_{t} s_{t+1}-s_{t}\right)
$$

If the interest rate differential is positive (i.e., $i_{t}^{*}-i_{t}>0$ ) and the USD depreciates against the foreign currency (i.e., $E_{t} s_{t+1}-s_{t}<0$ ), the excess return will be positive. It will also be positive if the USD appreciates against the foreign currency and this appreciation does not offset the interest rate differential. 


\section{B. Generalized Method of Moments}

In the paper we use the Fama-MacBeth approach with Shanken standad errors following Burnside (2011). However, we could also estimate our empirical asset pricing model using the generalized method of moments (GMM) proposed by Hansen (1982). As in Menkhoff et al. (2012), we use the first stage of the GMM procedure which has the identity weight matrix. Following Cochrane (2005) and Burnside (2011), the moment conditions are:

$$
\begin{array}{r}
{\left[1-b^{\prime}\left(h_{t}-\mu\right)\right] r_{t}=0} \\
h_{t}-\mu=0 \\
\operatorname{vec}\left(\left(h_{t}-\mu\right)\left(h_{t}-\mu\right)^{\prime}\right)-\operatorname{vec}\left(\Sigma_{h}\right)=0 .
\end{array}
$$

The first condition (A-2) is an $N$-dimensional vector that ensures the currency excess return satisfies the Euler equation. ${ }^{1}$ Equation (A-3) is an $l$-dimensional vector, indicating factor means $\mu$ are estimated values. The third condition (A-4) is an $l(l+1) / 2$ dimensional vector and measures the estimation uncertainty of the factor covariance matrix. These conditions account for estimation uncertainty, since the factor means and the covariance matrix are estimated values. We compute heteroskedasticity consistent standard errors as in Burnside (2011).

\section{Dynamic Hierarchical Factor Models}

We employ a four-level model with common, block, subblock and idiosyncratic components, as in Moench et al. (2013). Let $Z_{b k n, t}$ be the time-t observation of the $n$th series in subblock $k$, of block $b$. This is explained by the empirical factor $\left(H_{b k, t}\right)$ and idiosyncratic variation $\left(e_{Z b k n, t}\right)$. The four-level

\footnotetext{
${ }^{1} N$ is the number of the portfolios and $l$ is the number of the factors.
} 
factor model is then written as:

$$
\begin{aligned}
Z_{b k n, t} & =\Lambda_{H b k n}(L) H_{b k, t}+e_{Z b k n, t} \\
H_{b k, t} & =\Lambda_{G b k}(L) G_{b, t}+e_{H b k, t} \\
G_{b, t} & =\Lambda_{F b}(L) F_{t}+e_{G b, t}
\end{aligned}
$$

where $\Lambda_{j}(L)$, with $j=H b k n, G b k$ and $F b$, is a matrix of the time-invariant lag of loadings, and $L$ is the lag order. ${ }^{2}$ The matrix is lower triangular with ones on the diagonal to identify the factors and loadings. ${ }^{3}$ The subblock factor $H_{b k, t}$ is the latent factor of subblock $k$ at time $t$, and it captures the common movement in subblock $k$. This subblock factor $H_{b k, t}$ contains a block factor $G_{b, t}$ and a subblockspecific variation $e_{H b k, t}$. Similarly, in Equation (A-7) the block factor $G_{b, t}$ contains a common factor $F_{t}$ and a block-specific variation $e_{G b, t}$. Using Equations (A-6) and (A-7), the relation between the subblock factor $H_{b k, t}$ and the common factor $F_{t}$ can be written as:

$$
H_{b k, t}=\Lambda_{G b k}(L) \Lambda_{F b}(L) F_{t}+\Lambda_{G b k}(L) e_{G b, t}+e_{H b k, t} .
$$

The first term on the right hand side of Equation (A-8) is a time-varying intercept. Moreover, the data series $Z_{b k n, t}$ is linked to the common factor by Equations (A-5) and (A-8).

The idiosyncratic subblock-specific and block-specific variations, as well as the common factors, are assumed to be stationary, normally distributed autoregressive processes of order one, and evolve as

\footnotetext{
${ }^{2}$ We set the number of lags to zero as in Moench et al. (2013).

${ }^{3}$ Moench et al. (2013) posit that even in a two-level dynamic factor model, we cannot identify $\Lambda_{F b}(L)$ and $F_{t}$ without restrictions.
} 
follows: ${ }^{4}$

$$
\begin{aligned}
e_{Z b k n, t} & =\Psi_{Z b k n} e_{Z b k n, t-1}+\epsilon_{Z b k n, t} \\
e_{H b k, t} & =\Psi_{H b k} e_{H b k, t-1}+\epsilon_{H b k, t} \\
e_{G b, t} & =\Psi_{G b} e_{G b, t-1}+\epsilon_{G b, t} \\
F_{t} & =\Psi_{F} F_{t-1}+\epsilon_{F t}
\end{aligned}
$$

with $\epsilon_{j t} \sim N\left(0, \sigma_{j}^{2}\right)$, and $j=Z b k n, H b k, G b$ and $F . \Psi_{j}$ are $\mathrm{AR}(1)$ coefficients and all $\epsilon_{j, t}$ are uncorrelated across $j$ and over $t$. Prior to estimation, we transform the data to ensure stationarity using the method of Stock and Watson (2005). ${ }^{5}$

A standard method to estimate latent factors from a large number of data series is principal components. Principal components, however, would not account for potential relations between common and block factors and a time series structure such as that described in Equations (A-9) to (A-12). Moench et al. (2013) propose a Markov Chain Monte Carlo (MCMC) method to estimate the factor model. ${ }^{6}$ We follow this approach, employ the MCMC method and discard the first 20,000 draws as burn-in, and save every 100th of the remaining 50,000 draws.

\section{Country List}

The dataset covers the same 37 countries considered by Lustig et al. (2011): Australia, Austria, Belgium, Canada, Hong Kong, Czech Republic, Denmark, Euro area, Finland, France, Germany, Greece, Hungary, India, Indonesia, Ireland, Italy, Japan, Kuwait, Malaysia, Mexico, Netherlands, New Zealand, Norway, the Philippines, Poland, Portugal, Saudi Arabia, Singapore, South Africa, South Korea, Spain, Sweden, Switzerland, Taiwan, Thailand, and the United Kingdom. Developed country portfolios include: Australia, Belgium, Canada, Denmark, Euro area, France, Germany, Italy, Japan, Netherlands, New

\footnotetext{
${ }^{4}$ The DHFM can be set with different lag orders in $e_{Z b k n, t}, e_{H b k, t}, e_{G b, t}$ and $F_{t}$.

${ }^{5}$ When we use series different from those used by Stock and Watson (2005), we ensure the data is stationary based upon the Augmented Dickey Fuller (ADF) test.

${ }^{6}$ Initial values of the common, block, and subblock factors are estimated by principal components.
} 
Zealand, Norway, Sweden, Switzerland, and the United Kingdom. Emerging country portfolios are constructed from the other 22 currencies.

\section{E. Data Treatment}

We pre-treat the spot and forward rate dataset by following the same methodology used by Darvas (2009) and Cenedese et al. (2014). This involves using the previous day's observation if an observation exhibits any of the following: bid and ask rates are equal; the spread of the forward exchange rate is less than the spread of the spot exchange rate $;^{7}$ the daily spot rate changes but the daily forward rate stays constant and vice versa.

\section{F. Commodity Exporting and Importing Countries}

Following Ready et al. (2016), the commodity exporting countries include Australia (AUS), Canada (CAN), New Zealand (NZL), and Norway (NOR), and the commodity importing countries include the Euro (EUR), Germany (DEU), Japan (JPN), Sweden (SWE), and Switzerland (CHE). These two categories are based on the level of net exports in basic goods and net imports in finished goods.

\section{G. Country-level Asset Pricing}

We adopt a country-level asset pricing model as a robustness check. Lustig et al. (2011), and Ahmed and Valente (2015) argue that the country-level model can deal with the data-snooping biases mentioned by Lo and MacKinlay (1990), and the information problems presented by Ang et al. (2010). ${ }^{8}$

Following the Fama and MacBeth (1973) procedure, we run the first-stage time series regressions.

\footnotetext{
${ }^{7}$ Although some currencies in forward markets may have enough liquidity and smaller spreads than those in spot markets, our dataset contains many emerging currencies, and we simply follow this rule to standardize the data cleaning method.

${ }^{8}$ Lo and MacKinlay (1990) present evidence that finding a portfolio construction idea and testing it on the same dataset, leads to a data snooping bias. The bias may be serious when we use the portfolio approach. Ang et al. (2010) provide evidence that a risk premium depends upon the cross-sectional distribution of beta and idiosyncratic volatility. If we use portfolios, we lose some information of the beta distribution.
} 
The excess return $r_{i, t}$ of currency $i$ is regressed on DOL, factors estimated by DHFM, and a constant. We then run the following second-stage cross-sectional regression:

$$
r_{i, t}=\lambda_{D O L, t} \beta_{i, t}^{D O L}+\lambda_{h, t} \beta_{i, t}^{h}+\epsilon_{t}
$$

where $\lambda_{j, t}$ is the risk premium and $j=D O L$ or $h$, and $\beta_{i, t}^{j}$ is estimated by the first stage regression. We estimate this cross-sectional model for each $t$ and conduct statistical inference using mean $\lambda_{j}$ and variance $\sigma^{2}\left(\lambda_{j}\right)$ as in Cochrane (2005):

$$
\lambda_{j}=\frac{1}{T} \sum_{t=1}^{T} \lambda_{j, t}, \quad \sigma^{2}\left(\lambda_{j}\right)=\frac{1}{T^{2}} \sum_{t=1}^{T}\left(\lambda_{j, t}-\lambda_{j}\right)^{2} .
$$

Similar to Lustig et al. (2011), we use the Newey and West (1987) procedure to correct for autocorrelations.

\section{H. Empirical Results}

\section{G1. Descriptive Statistics}

Table A-1 provides descriptive statistics of the currency portfolio returns. Panel A contains statistics for all country results. The first and second rows report the annualized mean and standard deviation of excess return, respectively. We multiply the average monthly excess return by 12 and the monthly standard deviation by root 12 to obtain annualized values. Portfolio P1 contains the lowest interest rate currencies and portfolio P6 contains the highest interest rate currencies. P6 has the highest average excess return and the highest standard deviation. The return spread between P1 and P6 (i.e., High Minus Low, $\left.H M L_{F X}\right)$ is statistically different from zero at the $10 \%$ level. The third and fourth columns show the skewness and kurtosis. High interest portfolios, P5 and P6, have more negative skewness, and this result is similar to that of Menkhoff et al. (2012) and Dobrynskaya (2014). This negative skewness reflects the unwinding of carry trades, as suggested by Brunnermeier et al. (2009). 
The same return pattern is also seen for developed countries in Panel B of Table A-1. The emerging countries' result in Panel C provides a high $H M L_{F X}$. This result is consistent with Burnside et al. (2007) and Gilmore and Hayashi (2011). The mean excess returns in emerging countries are not monotonically increasing from P1 to P6 and the high trading cost might be the reason, as pointed out by Burnside et al. (2007).

\section{G2. Variance Decomposition}

Next, we present the results of a variance decomposition of our risk factors, which seeks to explain returns. Table A-2 reports the posterior means and standard deviations of estimated variance shares relative to the total variance as in Moench et al. (2013). Share ${ }_{F}$ is the variance share of common variations, and Share $_{G}$, Share ${ }_{H}$, and Share $_{Z}$ are the variance shares of block, subblock, and idiosyncratic variations, respectively.

First, we explore the commodity block. A single common factor does not appear to capture the commodity block variation. The block variation is important for oil, explaining $83 \%$ of total variance (Share $_{G}$ is equal to 0.825 for $S B-O I L$ ). The subblock variation has a larger share in the agricultural materials and the metals subblocks $\left(\right.$ Share $_{H}$ explains $15 \%$ and 23\%, respectively). This implies that there is a common component in the agricultural materials and the metals subblocks, respectively. The food subblock, in contrast, is largely explained by the idiosyncratic variation $\left(\right.$ Share $_{Z}$ has a posterior mean of 0.920 for $S B-F O O)$. These results present evidence of the extent of heterogeneity across different types of commodity groups.

We turn to the finance block in Table A-2 and the influence of the common variation is small for this information set. The finance variation is more substantial than the common variation in this group. For instance, the finance variation accounts for $31 \%$ of interest rate movements and $18 \%$ of the stock market, implying that the main driver of the finance block is the interest rate. 


\section{G3. Cross-sectional Results}

Given these promising commodity and stock market results, we next test whether a common factor across all blocks has information to price currency excess returns. Column (1) in Table A-3 reports the results of the common factor $(C O M M O N)$. These show that this common factor across the entire dataset is not related to the cross-section of currency excess returns, possibly because the broad common macro-finance factor is not sufficiently granular. For robustness, a common factor is also extracted from across the entire dataset by conventional principal component analysis and the results are reported in column (2). These confirm the conclusions drawn from the results reported in column (1) that commodity and stock market information need to be considered separately.

Next, the commodity common factor is tested and column (3) in Table A-3 presents the results, which also show a weak relationship between this factor and currency excess returns. The main driver of the commodity common factor is the oil subblock as shown in Table 1. This weak relationship is consistent with the results in Table A-3 suggesting that commodity subblock information is more important than common components. This implies that information heterogeneity across commodity blocks is crucial to the cross-sectional asset pricing model. It also implies that commodity prices are linked to a particular country's macro economic state and a country cannot hedge the specific-commodity price risk.

\section{G4. Time Series Results}

In this section, we conduct time series analyses on the factors identified above. If a factor can account for currency excess returns, currency portfolios should have significant exposure to this factor over time. The currency excess returns are regressed on a constant, DOL, and the agricultural material, metal, food, and stock market factors. The results are reported in Table A-4. Panel A reports the results using the agricultural factor. All estimated values of $\beta_{D O L}$ are around one and significant at the $1 \%$ level. All portfolios have almost the same exposure to $D O L$, which is a result that is consistent with Lustig et al. (2011). The estimated betas on the agricultural material factor, $\beta_{A G R}$ are statistically significant at the $1 \%$ level for $\mathrm{P} 1$ and $\mathrm{P} 6$. The negative coefficient of $\mathrm{P} 1$ and the positive risk premium imply that the lowest interest portfolio acts as a hedge against agricultural material risk. We also consider 
the economic impact of this factor. Since the standard deviation of the agricultural factor is 0.39 , a one-standard-deviation change in the agricultural material factor would reduce the annualized excess return of $\mathrm{P} 1$ by $2.9 \%$ and increase that of $\mathrm{P} 6$ by $3.3 \%$, all else equal. ${ }^{9}$

The results of the metal factor in Panel B have a similar pattern to those of the agricultural material factor. Interestingly, $\beta_{M E T}$ increase monotonically from $\mathrm{P} 1$ to $\mathrm{P} 6$, and those for $\mathrm{P} 1$ and $\mathrm{P} 6$ are statistically significant at the $1 \%$ and the $5 \%$ levels, respectively. In contrast, Panel $\mathrm{C}$ provides evidence that all factor betas on the food factor, $\beta_{F O O}$, are insignificant. This suggests that the factor betas used in the cross-sectional asset pricing model in Table 1 are not estimated with precision, because the betas using the cross-sectional regression in Table 1 have a weak relation with the food factor.

Finally, the results on the stock market factor are presented in Panel D. Apart from P1, the estimates of the coefficient on the stock market factor, $\beta_{S T O}$, increase monotonically from -0.49 for P2 to 0.78 for P6. P1, P2 and P6 have statistically significant betas. As the risk premium on the stock market factor is positive, as shown in Table 4, this result means P1 and P2 act as hedges against stock market risk. The standard deviation of the stock market factor is 0.35 and if the stock market factor changes by one standard deviation, the annualized excess return to P1 increases by $1.9 \%$ and the annualized excess return to P6 decreases by $3.3 \%$. This implies that the betas on the stock market factor have an economically significant impact on excess returns of currency portfolios.

\section{References for Online Appendix}

Ahmed, S. and Valente, G. (2015) Understanding the price of volatility risk in carry trades, Journal of Baking and Finance, 57, 118-129.

Ang, A. Liu, J., and Schwarz, K. (2010) Using stocks or portfolios in tests of factor models, unpublished working paper, Columbia University.

Brunnermeier, M. K., Nagel, S., and Pedersen, L. (2009) Carry Trades and Currency Crashes, NBER Macroeconomics Annual, 23, 313-347.

\footnotetext{
${ }^{9}$ This result is not reported in the table.
} 
Burnside, C. (2011) The cross section of foreign currency risk premia and consumption growth risk: comment, American Economic Review, 101, 3456-3476.

Burnside, C., Eichenbaum, M., and Rebelo, S. (2007) The returns to currency speculation in emerging markets American Economic Review, 97, 333-338

Cenedese, G. Sarno, L., and Tsiakas, I. (2014) Foreign exchange risk and the predictability of carry trade returns, Journal of Banking and Finance, 42, 302-313.

Cochrane, J. (2005), Asset pricing. Revised edition, Princeton: Princeton University Press.

Darvas, Z. (2009) Leveraged carry trade portfolios, Journal of Banking and Finance, 33, 944-957.

Engel, C. (1996) The forward discount anomaly and the risk premium: a survey of recent evidence, Journal of Empirical Finance, 3, 123-192.

Fama, F. and MacBeth, J. (1973) Risk, return, and equilibrium: empirical tests, Journal of Political Economy, 81, 607-636.

Gilmore, S. and Hayashi, F. (2011) Emerging market currency excess returns, American Economic Journal: Macroeconomics, 3, 85-111.

Hansen, L. (1982) Large sample properties of generalized method of moments estimations, Econometrica, 50, 1029-1054.

Lewis, K. (1995). Puzzles in international financial markets, in: Grossman, G and K. Rogoff (eds.), Handbook of International Economics, Vol. 3, North Holland: Elsevier, pp. 1913-1971.

Lo, A. and MacKinlay A. (1990) Data-snooping biases in tests of financial asset pricing models, Review of Financial Studies, 3, 431-467.

Lustig, H., Roussanov N., and Verdelhan, A. (2011) Common risk factors in currency markets, Review of Financial Studies. 24, 3731-3777. 
Newey, W. and West, K. (1987) A simple, positive semi-definite, heteroskedasticity and autocorrelation consistent covariance matrix, Econometrica, 55, 703-708.

Ready, R., Roussanov, N., and Ward, C. (2016) Commodity trade and the carry trade: a tale of two countries, Journal of Finance, in press.

Table A-1 Descriptive Statistics

\begin{tabular}{|c|c|c|c|c|c|c|c|}
\hline & $\mathrm{P} 1$ & P2 & P3 & $\mathrm{P} 4$ & $\mathrm{P} 5$ & $\mathrm{P} 6$ & $H M L_{F X}$ \\
\hline \multicolumn{8}{|c|}{ Panel A: All countries } \\
\hline \multirow[t]{2}{*}{ Mean } & 0.94 & -1.19 & 1.15 & $2.71^{*}$ & 0.88 & $4.08^{*}$ & $3.13^{*}$ \\
\hline & {$[0.58]$} & {$[-0.71]$} & {$[0.78]$} & {$[1.78]$} & {$[0.47]$} & {$[1.90]$} & {$[1.85]$} \\
\hline Std.dev. & 9.17 & 8.28 & 8.20 & 8.20 & 9.14 & 10.46 & 8.35 \\
\hline Skewness & 0.16 & -0.06 & -0.31 & -0.29 & -0.57 & -0.57 & -0.55 \\
\hline Kurtosis & 4.14 & 4.19 & 3.90 & 4.60 & 4.97 & 5.27 & 5.36 \\
\hline \multicolumn{8}{|c|}{ Panel B: Developed countries } \\
\hline \multirow[t]{2}{*}{ Mean } & 1.69 & -0.78 & 0.91 & 2.64 & $4.16^{* *}$ & & 2.48 \\
\hline & {$[0.90]$} & {$[-0.40]$} & {$[0.50]$} & {$[1.44]$} & {$[1.97]$} & & {$[1.46]$} \\
\hline Std.dev. & 10.50 & 9.77 & 9.49 & 9.28 & 10.44 & & 8.94 \\
\hline Skewness & 0.20 & -0.10 & -0.32 & -0.22 & -0.51 & & -0.72 \\
\hline Kurtosis & 3.46 & 3.55 & 3.85 & 5.27 & 4.55 & & 5.02 \\
\hline \multicolumn{8}{|c|}{ Panel C: Emerging countries } \\
\hline \multirow[t]{2}{*}{ Mean } & 0.40 & -1.82 & -0.52 & -0.90 & -4.89 & $7.35^{* *}$ & $6.59^{* *}$ \\
\hline & {$[0.22]$} & {$[-1.55]$} & {$[-0.38]$} & {$[-0.44]$} & {$[-1.57]$} & {$[2.00]$} & {$[2.17]$} \\
\hline Std.dev. & 7.59 & 4.48 & 5.65 & 8.23 & 12.06 & 12.15 & 10.68 \\
\hline Skewness & -0.68 & -0.17 & -0.78 & -0.26 & -2.74 & -0.85 & -0.62 \\
\hline Kurtosis & 8.80 & 4.78 & 5.44 & 5.16 & 19.23 & 6.24 & 4.77 \\
\hline
\end{tabular}

Notes: This table reports annualized mean, annualized standard deviations, skewness, and kurtosis of USD excess returns of currency portfolios sorted monthly at $t-1$ by forward discounts. $H M L_{F X}$ denotes a portfolio that is long in portfolio 6 (5) and short in portfolio 1 . Newey and West (1987) HAC $t$-statistics are reported in square brackets. *,**, and *** indicate significance at the $10 \%, 5 \%$ and 1\% levels, respectively. The sample period of all and developed countries is February 1983 to December 2013. The sample period of emerging countries is January 1997 to December 2013. 
Table A-2 Decomposition of Variance

\begin{tabular}{|c|c|c|c|c|c|c|c|c|c|}
\hline \multirow[t]{2}{*}{ Block } & \multirow[t]{2}{*}{ Subblock } & \multicolumn{2}{|c|}{ Share $_{F}$} & \multicolumn{2}{|c|}{ Share $_{G}$} & \multicolumn{2}{|c|}{ Share $_{H}$} & \multicolumn{2}{|c|}{ Share $_{Z}$} \\
\hline & & \multicolumn{8}{|c|}{ Posterior Mean (Standard Deviation) } \\
\hline$B-C O M$ & $S B-F O O$ & 0.001 & $(0.001)$ & 0.039 & $(0.015)$ & 0.040 & $(0.015)$ & 0.920 & $(0.030)$ \\
\hline$B-C O M$ & $S B-A G R$ & 0.001 & $(0.001)$ & 0.022 & $(0.011)$ & 0.147 & $(0.062)$ & 0.831 & $(0.069)$ \\
\hline$B-C O M$ & $S B-M E T$ & 0.002 & $(0.002)$ & 0.068 & $(0.020)$ & 0.233 & $(0.034)$ & 0.697 & $(0.043)$ \\
\hline$B-C O M$ & $S B-O I L$ & 0.027 & $(0.023)$ & 0.825 & $(0.025)$ & 0.084 & $(0.006)$ & 0.063 & $(0.009)$ \\
\hline$B-F I N$ & $S B-S T O$ & 0.000 & $(0.000)$ & 0.182 & $(0.021)$ & 0.151 & $(0.017)$ & 0.666 & (0.037) \\
\hline$B-F I N$ & $S B-I N T$ & 0.001 & $(0.001)$ & 0.312 & $(0.012)$ & 0.019 & $(0.002)$ & 0.668 & $(0.011)$ \\
\hline$B-F I N$ & $S B-M O N$ & 0.000 & $(0.000)$ & 0.001 & $(0.002)$ & 0.169 & $(0.009)$ & 0.830 & $(0.008)$ \\
\hline
\end{tabular}

Notes: This table displays the decomposition of variance based on Moench et al. (2013). Share $F$, Share Share $_{H}$, and Share $_{Z}$ denote the average of variance share across all variables in the subblock due to common, block-level, subblocklevel and idiosyncratic shocks, respectively. The commodity block has the following four subblocks: food prices (FOO), agricultural material prices $(A G R)$, metals $(M E T)$, and oil $(O I L)$. The finance block has the following three subblocks $(S B)$ : stock market $(S T O)$, interest rate $(I N T)$, and money $(M O N)$. 
Table A-3 Cross-sectional Asset Pricing: Common Factor

\begin{tabular}{|c|c|c|c|}
\hline & $\begin{array}{c}\text { (1) } \\
\lambda\end{array}$ & $\begin{array}{c}\text { (2) } \\
\lambda\end{array}$ & (3) \\
\hline$D O L$ & 0.16 & 0.16 & 0.16 \\
\hline & $(0.12)$ & $(0.12)$ & $(0.12)$ \\
\hline$C O M M O N$ & $\begin{array}{r}0.10 \\
(0.16)\end{array}$ & & \\
\hline$P C A F_{1}$ & & $\begin{array}{r}0.15 \\
(0.31)\end{array}$ & \\
\hline$B-C O M$ & & & $\begin{array}{r}0.48 \\
(0.30)\end{array}$ \\
\hline$R^{2}$ & 0.10 & 0.09 & 0.42 \\
\hline RMSE & 0.15 & 0.15 & 0.12 \\
\hline$\chi^{2}$ & $20.58^{* * * *}$ & $20.03^{* * *}$ & 5.96 \\
\hline$[p$-value $]$ & {$[0.00]$} & {$[0.00]$} & {$[0.20]$} \\
\hline
\end{tabular}

Notes: This table reports cross-sectional pricing results of the linear factor model based on the common risk factors. The test assets are excess returns of six carry trade portfolios. The coefficient of factor risk premium $\lambda$ in Equation (4) is estimated by the procedure of Fama and MacBeth (1973). Abbreviations of the factor variables are reported in the first column. $D O L$ is the average dollar risk factor. COMMON is the common and $B-C O M$ is the commodity factors estimated by the Dynamic Hierarchical Factor Model. $P C A F_{1}$ is the common factor obtained by a principal component. Shanken (1992) standard errors are reported in parentheses. The $R^{2}$ is a measure of fit between the sample mean and the predicted mean returns. The RMSE is the root of mean-squared error and is reported in percentage points. The $\chi^{2}$ test statistics of pricing errors are reported and the null hypothesis is that there is no pricing error. $p$-values are reported in square brackets. $* * *$, and $* * *$ indicate significance at the $10 \%, 5 \%$ and $1 \%$ levels, respectively. The sample period is from February 1983 to December 2013. 
Table A-4 Time Series Results

\begin{tabular}{|c|c|c|c|c|c|c|c|c|c|}
\hline \multicolumn{5}{|c|}{ Panel A: Factor Betas: $S B-A G R$} & \multicolumn{5}{|c|}{ Panel B: Factor Betas: $S B-M E T$} \\
\hline $\mathrm{P}$ & $\alpha$ & $\beta_{D O L}$ & $\beta_{A G R}$ & $\operatorname{adj} R^{2}$ & $\mathrm{P}$ & $\alpha$ & $\beta_{D O L}$ & $\beta_{M E T}$ & $\operatorname{adj} R^{2}$ \\
\hline 1 & $\begin{array}{c}-0.13^{*} \\
(0.07)\end{array}$ & $\begin{array}{l}1.02^{* * *} \\
(0.05)\end{array}$ & $\begin{array}{l}-0.62^{* * *} \\
(0.24)\end{array}$ & 0.77 & 1 & $\begin{array}{l}-0.14^{* *} \\
(0.07)\end{array}$ & $\begin{array}{l}1.03^{* * *} \\
(0.05)\end{array}$ & $\begin{array}{l}-0.63^{* * *} \\
(0.23)\end{array}$ & 0.77 \\
\hline 2 & $\begin{array}{l}-0.21^{* * *} \\
(0.06)\end{array}$ & $\begin{array}{l}0.93^{* * *} \\
(0.05)\end{array}$ & $\begin{array}{r}0.02 \\
(0.19)\end{array}$ & 0.80 & 2 & $\begin{array}{l}-0.21^{* * *} \\
(0.06)\end{array}$ & $\begin{array}{c}0.93^{* * *} \\
(0.04)\end{array}$ & $\begin{array}{r}-0.09 \\
(0.18)\end{array}$ & 0.80 \\
\hline 3 & $\begin{array}{l}-0.02 \\
(0.04)\end{array}$ & $\begin{array}{l}0.97^{\text {*** }} \\
(0.02)\end{array}$ & $\begin{array}{r}-0.07 \\
(0.11)\end{array}$ & 0.88 & 3 & $\begin{array}{r}-0.02 \\
(0.04)\end{array}$ & $\begin{array}{l}0.97^{\text {*** }} \\
(0.02)\end{array}$ & $\begin{array}{r}-0.05 \\
(0.10)\end{array}$ & 0.88 \\
\hline 4 & $\begin{array}{l}0.13^{* * *} \\
(0.05)\end{array}$ & $\begin{array}{c}0.93^{\text {*** }} \\
(0.03)\end{array}$ & $\begin{array}{r}0.04 \\
(0.14)\end{array}$ & 0.83 & 4 & $\begin{array}{l}0.13^{\text {*** }} \\
(0.05)\end{array}$ & $\begin{array}{l}0.94^{* * *} \\
(0.03)\end{array}$ & $\begin{array}{r}0.01 \\
(0.14)\end{array}$ & 0.83 \\
\hline 5 & $\begin{array}{l}-0.03 \\
(0.05)\end{array}$ & $\begin{array}{l}1.03^{\text {*** }} \\
(0.03)\end{array}$ & $\begin{array}{r}-0.05 \\
(0.15)\end{array}$ & 0.84 & 5 & $\begin{array}{r}-0.02 \\
(0.06)\end{array}$ & $\begin{array}{l}1.02^{\text {*** }} \\
(0.03)\end{array}$ & $\begin{array}{r}0.02 \\
(0.15)\end{array}$ & 0.84 \\
\hline 6 & $\begin{array}{l}0.26^{* * *} \\
(0.08)\end{array}$ & $\begin{array}{l}1.12^{* * *} \\
(0.04)\end{array}$ & $\begin{array}{l}0.69^{* * *} \\
(0.24)\end{array}$ & 0.76 & 6 & $\begin{array}{l}0.26^{* * *} \\
(0.08)\end{array}$ & $\begin{array}{l}1.11^{* * *} \\
(0.04)\end{array}$ & $\begin{array}{c}0.53^{* *} \\
(0.24)\end{array}$ & 0.76 \\
\hline & el C: Factor & Betas: $S L$ & $-F O O$ & & & el D: Fact & Betas: $S L$ & $-S T O$ & \\
\hline $\mathrm{P}$ & $\alpha$ & $\beta_{D O L}$ & $\beta_{F O O}$ & $\operatorname{adj} R^{2}$ & $\mathrm{P}$ & $\alpha$ & $\beta_{D O L}$ & $\beta_{S T O}$ & $\operatorname{adj} R^{2}$ \\
\hline 1 & $\begin{array}{c}-0.12^{*} \\
(0.07)\end{array}$ & $\begin{array}{l}1.01^{* * *} \\
(0.04)\end{array}$ & $\begin{array}{r}-0.23 \\
(0.20)\end{array}$ & 0.77 & 1 & $\begin{array}{c}-0.13^{*} \\
(0.07)\end{array}$ & $\begin{array}{l}1.01^{* * *} \\
(0.05)\end{array}$ & $\begin{array}{l}-0.44^{* * *} \\
(0.22)\end{array}$ & 0.76 \\
\hline 2 & $\begin{array}{l}-0.21^{* * *} \\
(0.06)\end{array}$ & $\begin{array}{c}0.93^{\text {*** }} \\
(0.04)\end{array}$ & $\begin{array}{c}-0.14 \\
(0.21)\end{array}$ & 0.80 & 2 & $\begin{array}{l}-0.22^{* * *} \\
(0.06)\end{array}$ & $\begin{array}{l}0.94^{* * *} \\
(0.04)\end{array}$ & $\begin{array}{l}-0.49^{* * *} \\
(0.19)\end{array}$ & 0.80 \\
\hline 3 & $\begin{array}{r}-0.02 \\
(0.04)\end{array}$ & $\begin{array}{l}0.96^{* * *} \\
(0.02)\end{array}$ & $\begin{array}{r}0.09 \\
(0.10)\end{array}$ & 0.88 & 3 & $\begin{array}{r}-0.02 \\
(0.04)\end{array}$ & $\begin{array}{l}0.97^{* * *} \\
(0.02)\end{array}$ & $\begin{array}{r}-0.19 \\
(0.13)\end{array}$ & 0.88 \\
\hline 4 & $\begin{array}{l}0.13^{* * *} \\
(0.05)\end{array}$ & $\begin{array}{l}0.93^{\text {*** }} \\
(0.03)\end{array}$ & $\begin{array}{r}0.13 \\
(0.12)\end{array}$ & 0.83 & 4 & $\begin{array}{l}0.13^{\text {*** }} \\
(0.05)\end{array}$ & $\begin{array}{l}0.93^{\text {*** }} \\
(0.04)\end{array}$ & $\begin{array}{r}0.19 \\
(0.15)\end{array}$ & 0.83 \\
\hline 5 & $\begin{array}{r}-0.03 \\
(0.05)\end{array}$ & $\begin{array}{l}1.03^{* * *} \\
(0.03)\end{array}$ & $\begin{array}{r}-0.08 \\
(0.13)\end{array}$ & 0.84 & 5 & $\begin{array}{r}-0.03 \\
(0.05)\end{array}$ & $\begin{array}{l}1.03^{\text {*** }} \\
(0.03)\end{array}$ & $\begin{array}{r}0.23 \\
(0.15)\end{array}$ & 0.84 \\
\hline 6 & $\begin{array}{l}0.25^{* * *} \\
(0.09)\end{array}$ & $\begin{array}{l}1.13^{\text {*** }} \\
(0.04)\end{array}$ & $\begin{array}{r}0.21 \\
(0.21) \\
\end{array}$ & 0.76 & 6 & $\begin{array}{l}0.26^{* * * *} \\
(0.08)\end{array}$ & $\begin{array}{l}1.12^{\text {*** }} \\
(0.04)\end{array}$ & $\begin{array}{l}0.78^{* * *} \\
(0.24)\end{array}$ & 0.76 \\
\hline
\end{tabular}

Notes: This table presents of time series regressions of excess returns of carry trade portfolios on a constant $(\alpha)$, the average dollar risk $(D O L)$, and subblock factors. $S B-A G R$ is the agricultural material prices, and $S B-M E T$ is the metal, $S B-F O O$ is the food prices, and $S B-S T O$ is the stock market factors estimated by the Dynamic Hierarchical Factor Model. The standard errors are reported in parentheses and obtained by the Newey and West (1987) procedure with optimal lag selection according to Andrews (1991). The adjusted $R^{2}$ are also reported. ***, and *** indicate significance at the 10\%, 5\% and 1\% levels, respectively. The sample period is from February 1983 and December 2013. 
Table A-5 Data and Model Structure

\begin{tabular}{cll}
\hline Block & Subblock & $N$ \\
\hline$B-C O M$ & $S B-F O O$ & 6 \\
$B-C O M$ & $S B-A G R$ & 6 \\
$B-C O M$ & $S B-M E T$ & 3 \\
$B-C O M$ & $S B-O I L$ & 6 \\
$B-F I N$ & $S B-S T O$ & 15 \\
$B-F I N$ & $S B-I N T$ & 13 \\
$B-F I N$ & $S B-M O N$ & 9 \\
$B-E C O$ & $S B-I N C$ & 14 \\
$B-E C O$ & $S B-P R O$ & 25 \\
$B-E C O$ & $S B-E M P$ & 10 \\
$B-E C O$ & $S B-H O U$ & 14 \\
\hline
\end{tabular}

Notes: This table summarizes the block structure of the four-level Dynamic Hierarchical Factor Model. $N$ is the number of series in each subblock. There are three blocks $(B)$ : commodity price $(C O M)$, finance $(F I N)$ and real economy $(E C O)$. The commodity block has four subblocks $(S B)$ : food prices $(F O O)$, agricultural material prices $(A G R)$, metals $(M E T)$, and oil $(O I L)$. The finance block has three subblocks $(S B)$ : stock market $(S T O)$, interest rate $(I N T)$, and money $(M O N)$. The real economy block has five subblocks: income and consumption $(I N C)$, production $(P R O)$, employment $(E M P)$, house $(H O U)$, and price $(P R I)$. 
Table A-6 Cross-sectional Asset Pricing: Commodity and Finance Subblocks without Bid Ask Spreads

\begin{tabular}{|c|c|c|c|c|}
\hline \multicolumn{5}{|c|}{ Panel A: Commodity Block } \\
\hline Panel A: Cor & $\begin{array}{l}\text { modity Block } \\
\text { (1) }\end{array}$ & (2) & (3) & (4) \\
\hline & $\lambda$ & $\lambda$ & $\lambda$ & $\lambda$ \\
\hline$\overline{D O L}$ & 0.24 & 0.24 & 0.24 & 0.25 \\
\hline & $(0.12)$ & $(0.12)$ & $(0.12)$ & $(0.12)$ \\
\hline$S B-A G R$ & $\begin{array}{l}0.63^{\text {*** }} \\
(0.17)\end{array}$ & & & \\
\hline$S B-M E T$ & & $\begin{array}{l}0.73^{\text {*** }} \\
(0.24)\end{array}$ & & \\
\hline$S B-F O O$ & & & $\begin{array}{c}1.37^{*} \\
(0.70)\end{array}$ & \\
\hline$S B-O I L$ & & & & $\begin{array}{r}0.78 \\
(0.93)\end{array}$ \\
\hline$R^{2}$ & 0.90 & 0.87 & 0.73 & 0.09 \\
\hline RMSE & 0.08 & 0.09 & 0.14 & 0.25 \\
\hline$\chi^{2}$ & 2.84 & 3.55 & 2.20 & $27.72^{* * * *}$ \\
\hline [p-value] & {$[0.58]$} & {$[0.47]$} & {$[0.70]$} & {$[0.00]$} \\
\hline
\end{tabular}

Panel B: Finance Block

\begin{tabular}{lccc} 
& $(5)$ & $(6)$ & $(7)$ \\
& $\lambda$ & $\lambda$ & $\lambda$ \\
\hline$D O L$ & 0.23 & 0.24 & 0.24 \\
$S B-S T O$ & $0.12)$ & $(0.12)$ & $(0.12)$ \\
& $0.51^{* * *}$ & & \\
$S B-I N T$ & $(0.14)$ & -3.93 & \\
& & $(2.71)$ & $-0.48^{* * *}$ \\
$S B-M O N$ & & & $(0.17)$ \\
& & & \\
$R^{2}$ & 0.86 & 0.50 & 0.31 \\
RMSE & 0.10 & 0.18 & 0.22 \\
$\chi^{2}$ & 5.82 & 2.02 & $13.62^{* *}$ \\
{$[p$-value $]$} & {$[0.21]$} & {$[0.73]$} & {$[0.01]$} \\
\hline
\end{tabular}

Notes: This table reports cross-sectional pricing results of the cross-sectional pricing results of the linear factor model based on the commodity prices or financial risk factors. The test assets are excess returns of six carry trade portfolios without trading costs. The coefficient of factor risk premium $\lambda$ in Equation (4) is estimated by the procedure of Fama and MacBeth (1973). Abbreviations of the factor variables are reported in the first column. $D O L$ is the average dollar risk factor. $S B-F O O$ is food prices, $S B-A G R$ is agricultural material prices, $S B-M E T$ is metal prices, $S B-O I L$ is oil prices, $S B-S T O$ is stock market, $S B-I N T$ is interest rate, and $S B-M O N$ is money factors estimated by the Dynamic Hierarchical Factor Model. Shanken (1992) standard errors are reported in parentheses. The $R^{2}$ is a measure of fit between the sample mean and the predicted mean returns. The RMSE is the root of mean-squared error and is reported in percentage points. The $\chi^{2}$ test statistics of pricing errors are reported and the null hypothesis is that there is no pricing error. $p$-values are reported in square brackets. ${ }^{*}, * *$, and $* * *$ indicate significance at the $10 \%, 5 \%$ and $1 \%$ levels, respectively. The sample period is from February 1983 to December 2013. 
Table A-7 Cross-sectional Asset Pricing: GMM

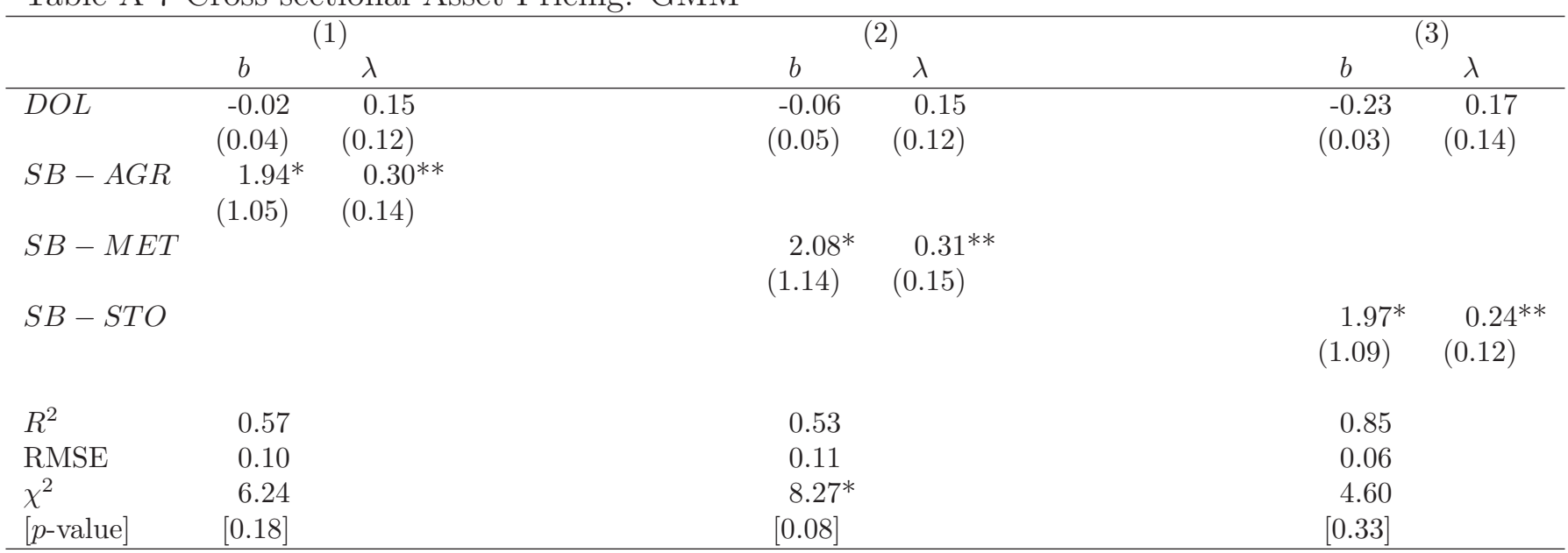

Notes: This table reports cross-sectional pricing results of the linear factor model based on the commodity prices or financial risk factors. The test assets are excess returns of six carry trade portfolios. Coefficients of SDF parameter $b$ and factor risk premium $\lambda$ are estimated by GMM, and the first stage GMM results are reported. Abbreviations of the factor variables are reported in the first column. $D O L$ is the average dollar risk factor. $S B-A G R$ is the agricultural material prices, $S B-M E T$ is the metal, and $S B-S T O$ is the stock market factors estimated by the Dynamic Hierarchical Factor Model. GMM-VARHAC standard errors are reported in parentheses. The $R^{2}$ is a measure of fit between the sample mean and the predicted mean returns. The RMSE is the root of mean-squared error and is reported in percentage points. The $\chi^{2}$ test statistics of pricing errors are reported and the null hypothesis is that there is no pricing error. $p$-values are reported in square brackets. ${ }^{*}, * *$, and $* * *$ indicate significance at the $10 \%, 5 \%$ and $1 \%$ levels, respectively. The sample period is from February 1983 to December 2013. 
Table A-8 Cross-sectional Asset Pricing: Commodity Index

\begin{tabular}{|c|c|c|c|c|c|}
\hline & (1) & (2) & (3) & (4) & (5) \\
\hline & $\lambda$ & $\lambda$ & $\lambda$ & $\lambda$ & $\lambda$ \\
\hline$\overline{D O L}$ & 0.16 & 0.16 & 0.15 & 0.15 & 0.16 \\
\hline & $(0.12)$ & $(0.12)$ & $(0.12)$ & $(0.12)$ & $(0.12)$ \\
\hline$C R B$ & $\begin{array}{r}3.94 \\
(2.60)\end{array}$ & & & & \\
\hline$I M F-A G R$ & & $\begin{array}{r}0.81 \\
(1.03)\end{array}$ & & & \\
\hline$I M F-M E T$ & & & $\begin{array}{l}4.03^{* *} \\
(1.95)\end{array}$ & $\begin{array}{l}-0.65 \\
(3.08)\end{array}$ & \\
\hline$I M F-M E T^{\text {orth }}$ & & & & & $\begin{array}{r}-3.57 \\
(3.01)\end{array}$ \\
\hline$S B-M E T$ & & & & & $\begin{array}{c}0.33^{*} \\
(0.18)\end{array}$ \\
\hline$S B-M E T^{\text {orth }}$ & & & & $\begin{array}{c}0.38^{*} \\
(0.22)\end{array}$ & \\
\hline$R^{2}$ & 0.38 & 0.10 & 0.43 & 0.61 & 0.61 \\
\hline RMSE & 0.13 & 0.15 & 0.12 & 0.10 & 0.10 \\
\hline$\chi^{2}$ & 7.75 & $19.61^{* * *}$ & $12.32^{* *}$ & 5.35 & 5.35 \\
\hline [p-value] & {$[0.10]$} & {$[0.00]$} & {$[0.02]$} & {$[0.15]$} & {$[0.15]$} \\
\hline
\end{tabular}

Notes: This table reports cross-sectional pricing results of the linear factor model based on the commodity prices factors. The test assets are excess returns of six carry trade portfolios without trading costs. The coefficient of factor risk premium $\lambda$ in Equation (4) is estimated by the procedure of Fama and MacBeth (1973). Abbreviations of the factor variables are reported in the first column. $D O L$ is the average dollar risk factor. $C R B$ is the CRB Raw industrial material subkinex return as in Bakshi and Pnayotov (2013). IMF - AGR is the IMF agricultural material index, IMF - MET is the IMF metal index, and both are computed as real returns. IMF-MET ${ }^{\text {orth }}$ is the orthogonalized IMF metal index real return. $S B-M E T$ is the metal factor estimated by the Dynamic Hierarchical Factor Model and $S B-M E T^{\text {orth }}$ is the orthogonalized metal factor. The $R^{2}$ is a measure of fit between the sample mean and the predicted mean returns. The RMSE is the root of mean-squared error and is reported in percentage points. The $\chi^{2}$ test statistics of pricing errors are reported and the null hypothesis is that there is no pricing error. $p$-values are reported in square brackets. ${ }^{* * *}$, and ${ }^{* * *}$ indicate significance at the $10 \%, 5 \%$ and $1 \%$ levels, respectively. The sample period is from February 1983 to December 2013. 
Table A-9 Country-level Asset Pricing

\begin{tabular}{|c|c|c|c|}
\hline & $\begin{array}{c}(1) \\
\lambda\end{array}$ & $\begin{array}{c}(2) \\
\lambda\end{array}$ & $\begin{array}{c}(3) \\
\lambda\end{array}$ \\
\hline$D O L$ & $\begin{array}{c}0.27^{* *} \\
(0.13)\end{array}$ & $\begin{array}{c}0.24^{* *} \\
(0.13)\end{array}$ & $\begin{array}{c}0.26^{* *} \\
(0.13)\end{array}$ \\
\hline$S B-A G R$ & $\begin{array}{c}0.18^{* *} \\
(0.09)\end{array}$ & & \\
\hline$S B-M E T$ & & $\begin{array}{l}0.18^{* *} \\
(0.07)\end{array}$ & \\
\hline$S B-S T O$ & & & $\begin{array}{c}0.08^{*} \\
(0.04)\end{array}$ \\
\hline$R^{2}$ & 0.25 & 0.28 & 0.29 \\
\hline RMSE & 1.58 & 1.54 & 1.52 \\
\hline
\end{tabular}

Notes: This table reports cross-sectional pricing results using individual currencies. The factor risk premium $\lambda$ is obtained by Equations (A-5) and (A-6). Abbreviations of the factor variables are reported in the first column. $D O L$ is the average dollar risk factor. $S B-A G R$ is the agricultural material prices, $S B-M E T$ is the metal, and $S B-S T O$ is the stock market factors estimated by the Dynamic Hierarchical Factor Model. The standard errors are reported in parentheses and obtained by the Newey and West (1987) procedure with optimal lag selection according to Andrews (1991). The $R^{2}$ and RMSE is average of time series. The RMSE is the root mean-squared error and is reported in percentage points. *,**, and $* * *$ indicate significance at the $10 \%, 5 \%$ and $1 \%$ levels, respectively. The sample period is from February 1983 to December 2013. 
Table A-10 Time Series Regression with $H M L_{F X}$

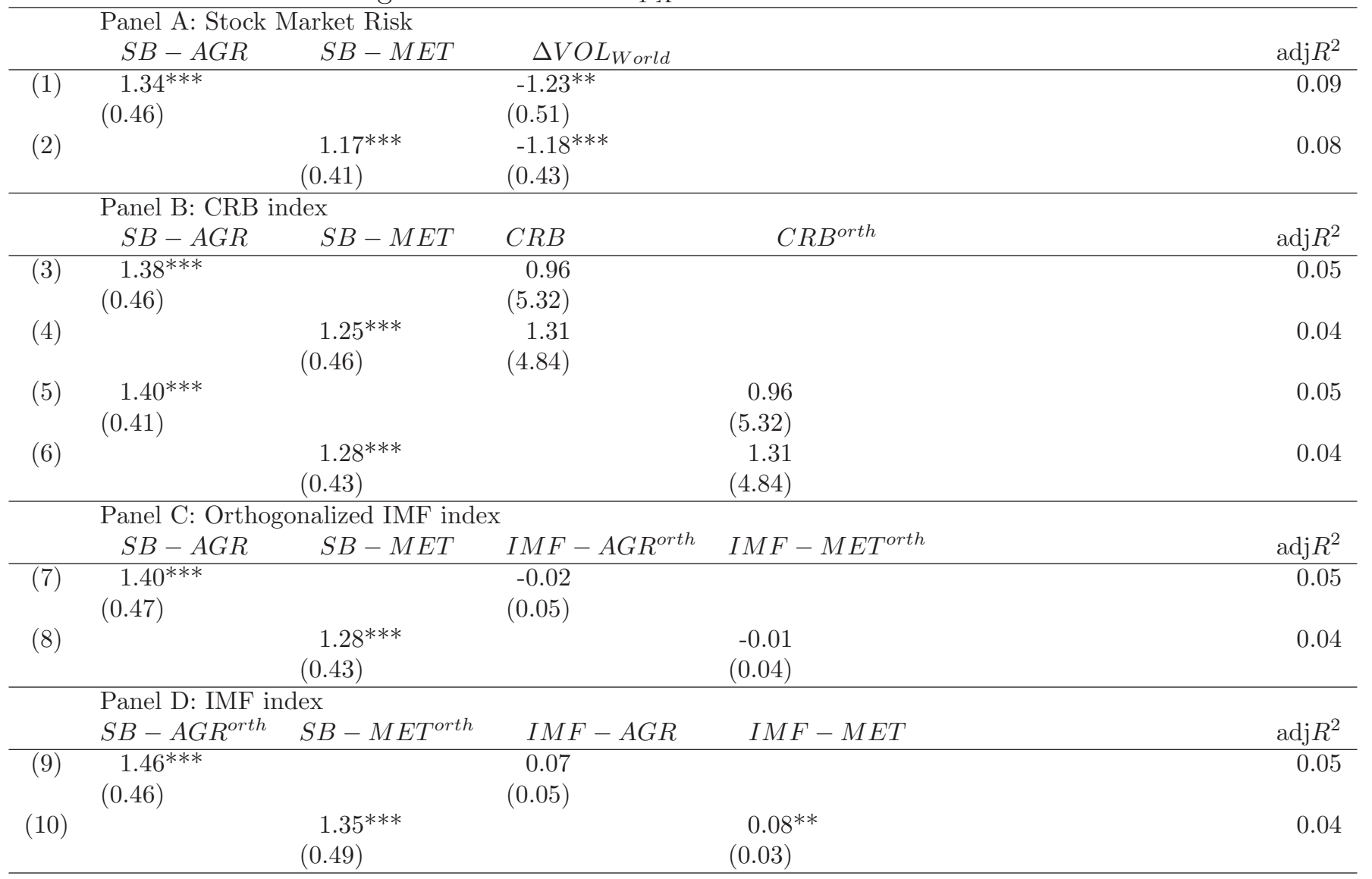

Notes: This table shows results for time series regressions of $H M L_{F X}$ on a constant $(\alpha)$ and factors. $H M L_{F X}$ is the high minus low currency portfolios as in Lustig et al. (2011). $S B-A G R$ is the agricultural material prices, $S B-M E T$ is the metals factors estimated by the Dynamic Hierarchical Factor Model. $S B-A G R^{\text {orth }}$ is the orthogonalized agricultural material prices, $S B-M E T^{\text {orth }}$ is the orthogonalized metals factors. $\triangle V O L_{\text {world }}$ is the global stock market volatility innovations using MSCI World index. $C R B$ is the CRB Raw industrial material subkinex return as in Bakshi and Panayotov (2013), $C R B^{\text {orth }}$ is the the orthogonalized CRB Raw industrial material subkinex return. IMF - AGR is the IMF agricultural material index, IMF - MET is the IMF metals index, and both are computed as a real return. $I M F-A G R^{\text {orth }}$ is the IMF agricultural material index, IMF-MET ${ }^{\text {orth }}$ is the IMF metals index, and both are computed as a orthogonalized real return. The estimation results of constant term are not reported. The standard errors are reported in parentheses and obtained by the Newey and West (1987) procedure with optimal lag selection according to Andrews (1991). The adjusted $R^{2}$ are also reported. ***, and *** indicate significance at the $10 \%, 5 \%$ and $1 \%$ levels, respectively. The sample period is from February 1983 and December 2013. 


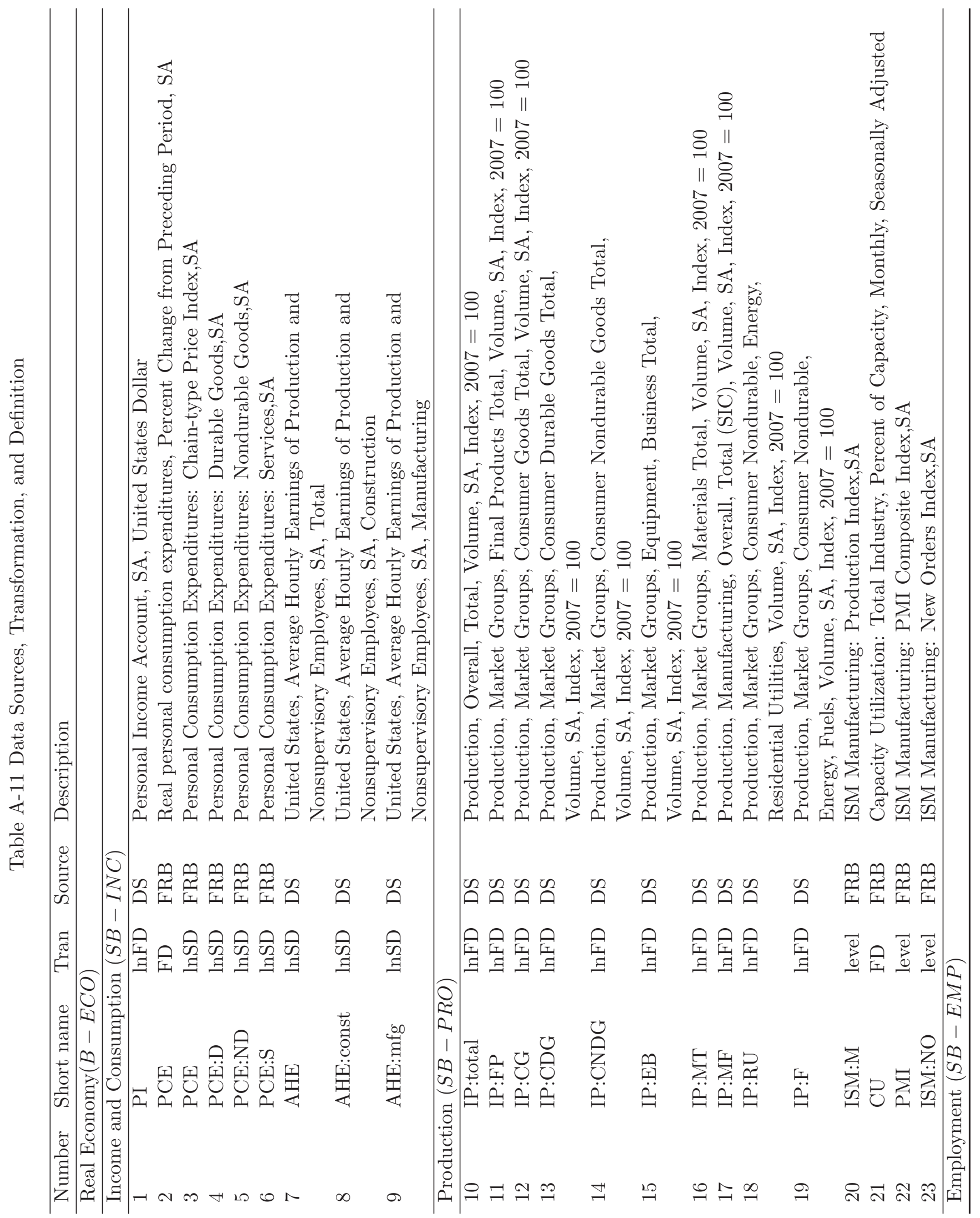




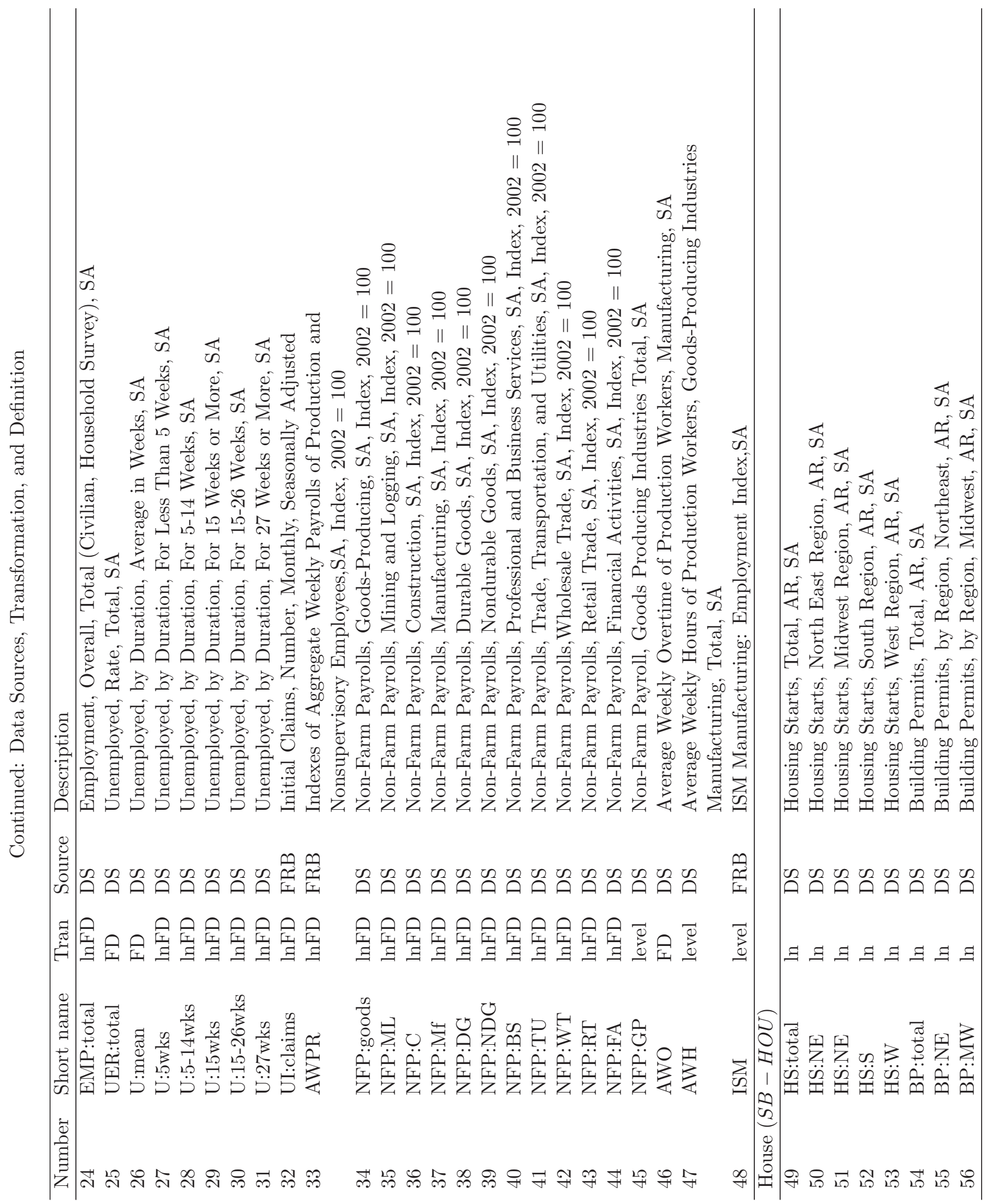




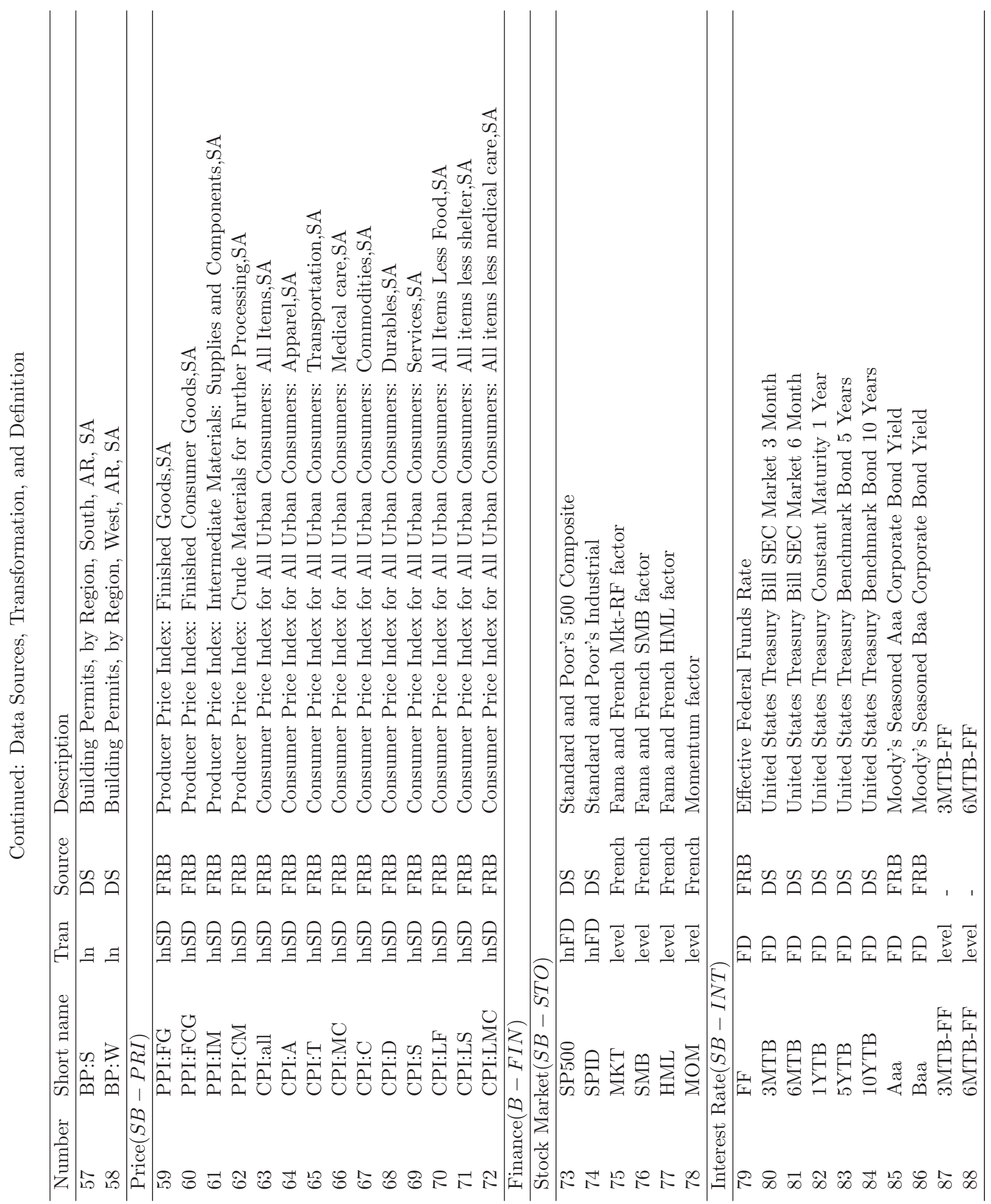




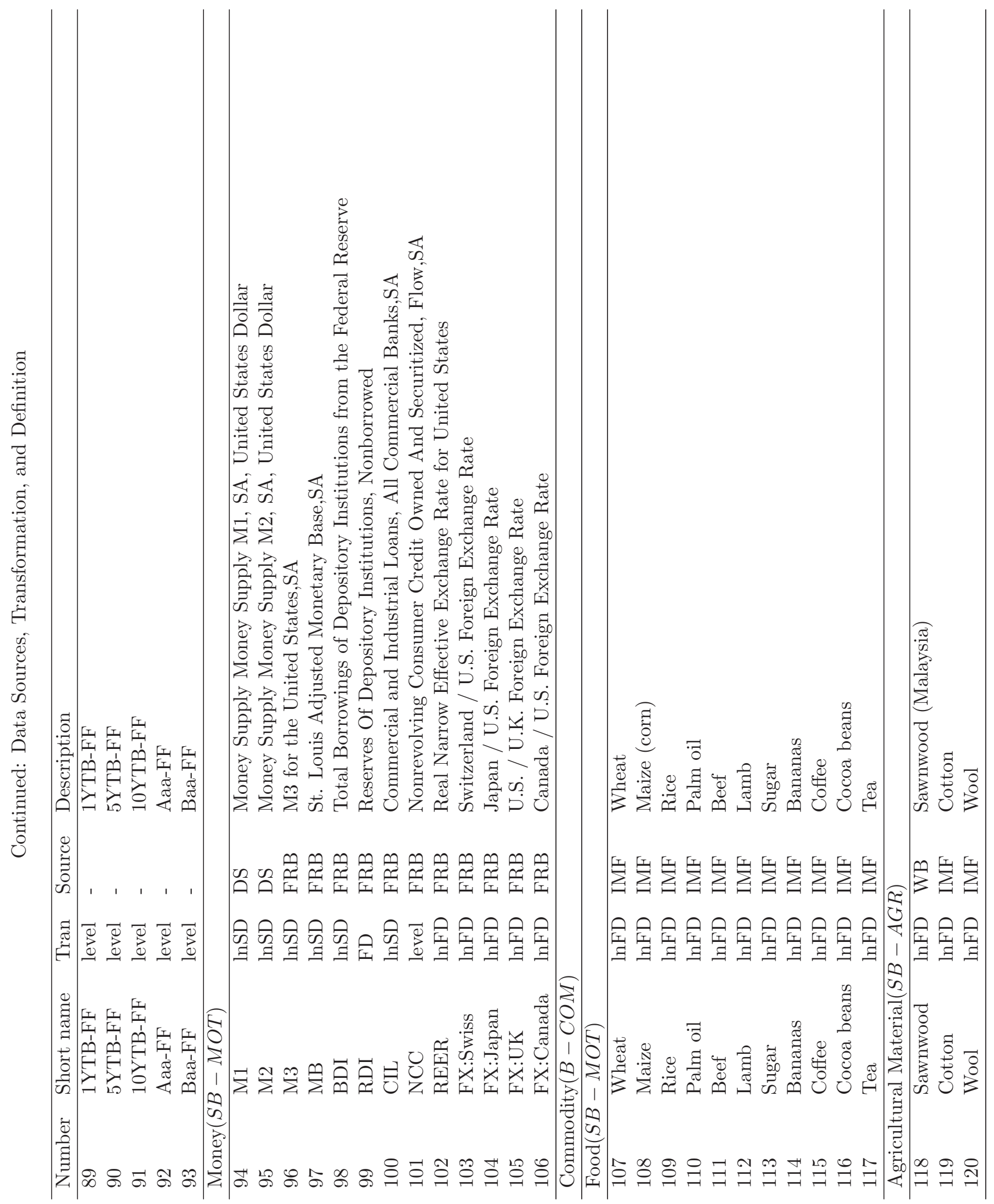




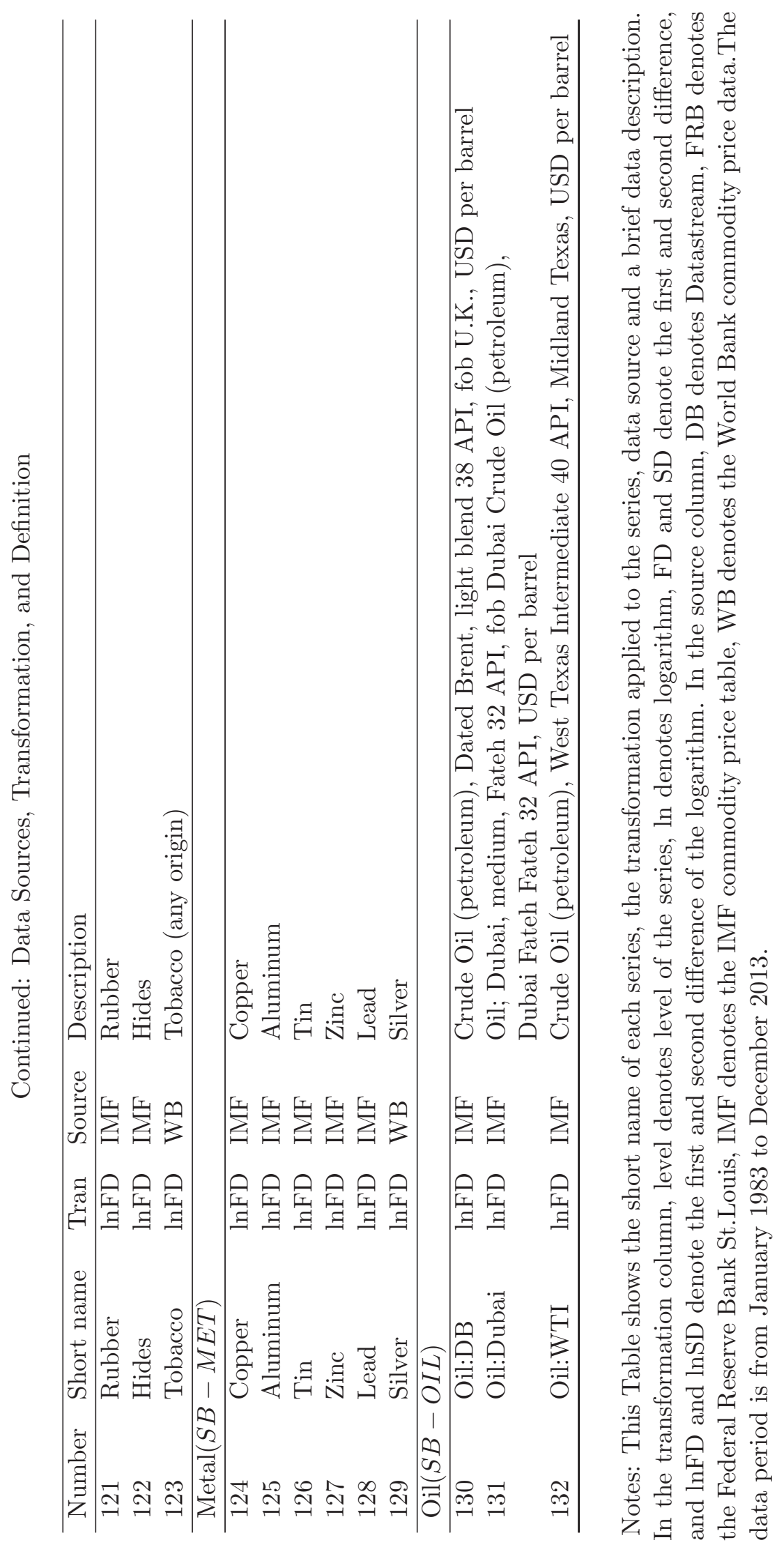


Graph A. $S B-A G R$

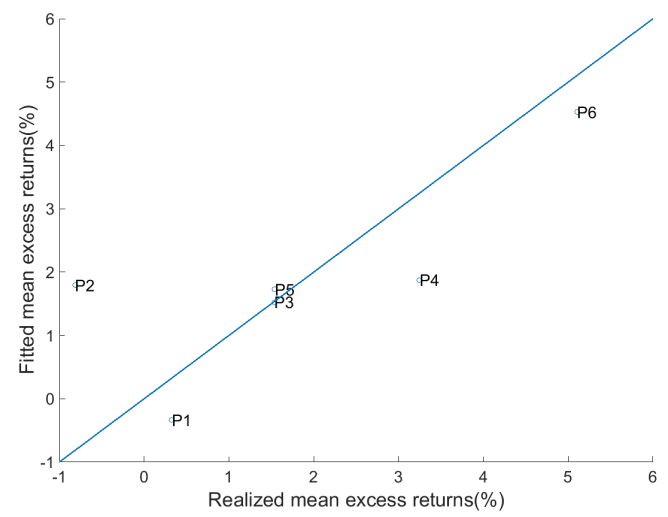

Graph C. $S B-S T O$

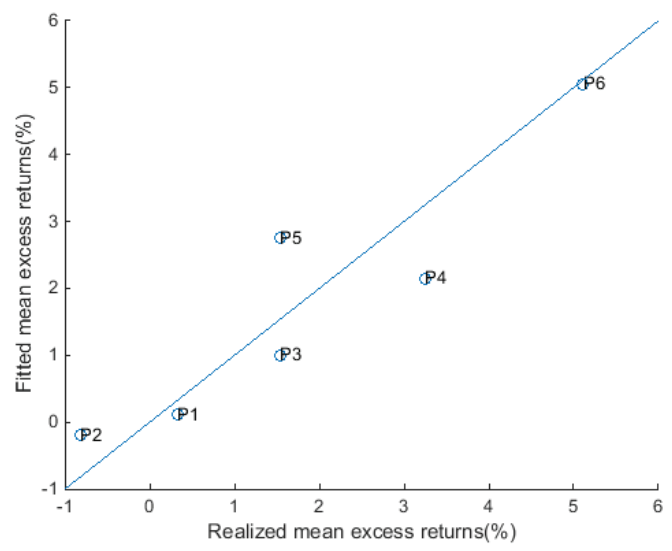

Graph C. $S B-M E T$

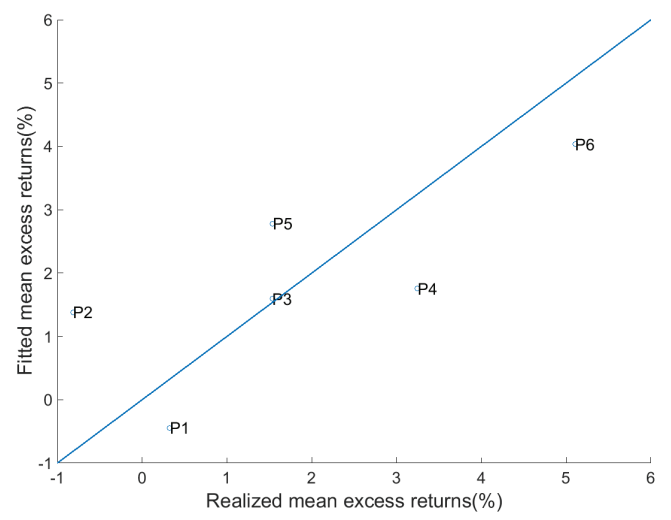

Figure A-1. Pricing Error Plots.

Figure 1 displays pricing errors for asset pricing models with a combination of $D O L$ and a subblock factor. The realized mean excess returns $\left(r_{i, t}\right)$ are on the horizontal axis and the mean fitted excess returns are on the vertical axis. Both excess returns are annualized returns. Graph A uses the agricultural material prices subblock $(S B-A G R)$, Graph B uses the the metals subblock $(S B-M E T)$, Graph $\mathrm{C}$ uses the stock market $(S B-S T O)$ factors estimated by the Dynamic Hierarchical Factor Model. The sample period is from February 1983 to December 2013. 
Graph A. Agricultural Factor

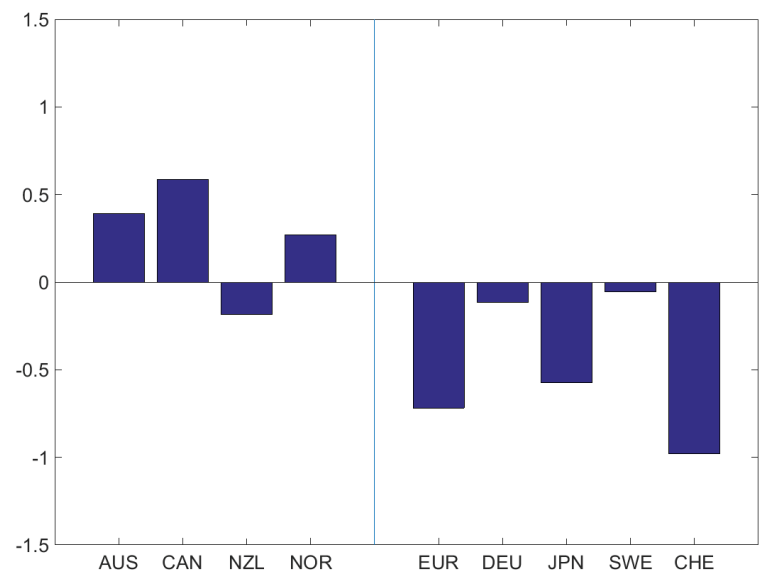

Graph B. Metal Factor

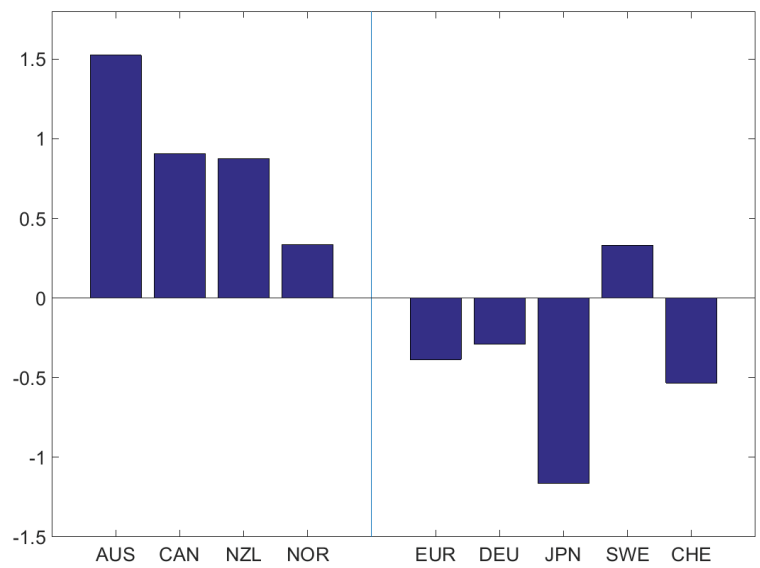

Figure A-2. Country Betas to Agricultural Material Price and Metal Factors.

Figure A-1 shows factor betas which are obtained by the time series regressions. The basic sample period is from February 1983 to December 2013. Australia starts from November 1989, Euro starts from February 1999, New Zealand starts from August 1990, and Germany ends December 1998. 